\title{
Combination of the BeWo b30 placental transport model and the embryonic stem cell test to assess the potential developmental toxicity of silver nanoparticles
}

\author{
Ashraf Abdelkhaliq ${ }^{1,2,3}$, Meike van der Zande ${ }^{2}$, Ruud J. B. Peters ${ }^{2}$ and Hans Bouwmeester ${ }^{1 *}$
}

\begin{abstract}
Background: Silver nanoparticles (AgNPs) are used extensively in various consumer products because of their antimicrobial potential. This requires insight in their potential hazards and risks including adverse effects during pregnancy on the developing fetus. Using a combination of the BeWo b30 placental transport model and the mouse embryonic stem cell test (EST), we investigated the capability of pristine AgNPs with different surface chemistries and aged AgNPs (silver sulfide $\left(\mathrm{Ag}_{2} \mathrm{~S}\right) \mathrm{NPs}$ ) to cross the placental barrier and induce developmental toxicity. The uptake/ association and transport of AgNPs through the BeWo b30 was characterized using ICP-MS and single particle (sp)|CPMS at different time points. The developmental toxicity of the AgNPs was investigated by characterizing their potential to inhibit the differentiation of mouse embryonic stem cells (mESCs) into beating cardiomyocytes.

Results: The AgNPs are able to cross the BeWo b30 cell layer to a level that was limited and dependent on their surface chemistry. In the EST, no in vitro developmental toxicity was observed as the effects on differentiation of the mESCs were only detected at cytotoxic concentrations. The aged AgNPs were significantly less cytotoxic, less bioavailable and did not induce developmental toxicity.

Conclusions: Pristine AgNPs are capable to cross the placental barrier to an extent that is influenced by their surface chemistry and that this transport is likely low but not negligible. Next to that, the tested AgNPs have low intrinsic potencies for developmental toxicity. The combination of the BeWo b30 model with the EST is of added value in developmental toxicity screening and prioritization of AgNPs.
\end{abstract}

Keywords: Silver nanoparticles, Surface chemistry, Placental transport, Embryotoxicity, Single particle-ICP-MS

\section{Background}

Engineered nanoparticles (NPs) have gained much attention in the last decades due to their unique properties compared to the corresponding bulk material, resulting

\footnotetext{
* Correspondence: hans.bouwmeester@wur.nl

'Division of Toxicology, Wageningen University, P.O. box 8000, 6700, EA, Wageningen, the Netherlands

Full list of author information is available at the end of the article
}

in applications in a wide diversity of products [1-3]. Silver nanoparticles (AgNPs) are used in very diverse consumer related products such as textile, toys, and food containers, where they are generally applied because of their antimicrobial properties $[4,5]$. This widespread use has increased the potential for human exposure to AgNPs [6].

Humans can be exposed to various forms and types of AgNPs resulting from their release during a product's

(c) The Author(s). 2020 Open Access This article is licensed under a Creative Commons Attribution 4.0 International License, which permits use, sharing, adaptation, distribution and reproduction in any medium or format, as long as you give appropriate credit to the original author(s) and the source, provide a link to the Creative Commons licence, and indicate if changes were made. The images or other third party material in this article are included in the article's Creative Commons licence, unless indicated otherwise in a credit line to the material. If material is not included in the article's Creative Commons licence and your intended use is not permitted by statutory regulation or exceeds the permitted use, you will need to obtain permission directly from the copyright holder. To view a copy of this licence, visit http://creativecommons.org/licenses/by/4.0/ The Creative Commons Public Domain Dedication waiver (http://creativecommons.org/publicdomain/zero/1.0/) applies to the data made available in this article, unless otherwise stated in a credit line to the data. 
life cycle [7]. AgNPs with different chemical surface modifications are currently being explored to find the optimum between maximal functionality for the application balanced against minimal toxicological hazards, which is known as the Safe-by-Design approach [8, 9]. Upon release of AgNPs into the environment, they are susceptible to sulfidation processes resulting in silver sulfide nanoparticles $\left(\mathrm{Ag}_{2} \mathrm{~S} \mathrm{NPs}\right)$, which are considered the main form of particulate silver in the environment [10]. In addition, in vivo systemically available AgNPs or ionic silver have also been shown to transform into $\mathrm{Ag}_{2} \mathrm{~S}$ NPs [11]. Direct use of $\mathrm{Ag}_{2} \mathrm{~S}$ NPs has also been described in engineering and biomedical applications $[10,12]$. $\mathrm{Ag}_{2} \mathrm{~S}$ NPs have been shown to be stable in soils resulting in a potential uptake and accumulation of $\mathrm{Ag}_{2} \mathrm{~S}$ NPs in plants and the human food chain [13]. In our studies, we therefore not only included AgNPs with different chemical surface modifications, but also $\mathrm{Ag}_{2} \mathrm{~S}$ NPs.

Previously, we studied the potential transport of AgNPs with different surface modifications across monolayers of intestinal epithelial cells in vitro [14]. We showed that in vitro simulated human digestion had a drastic effect on the dissolution of AgNPs, an effect that was surface coating dependent. A concentration dependent cellular uptake and/or association, albeit low, was observed. Also available sub-chronic data from rodent studies indicate systemic uptake and retention of $\mathrm{Ag}$ in tissues [11, 15]. Therefore, in the current work we assessed whether AgNPs would also be able to pass the placental barrier and if so, to what extent. In addition, to obtain further insight in possible hazards for the developing fetus, the in vitro developmental toxicity of the AgNPs was investigated using the mouse embryonic stem cell test (EST).

The placental barrier has received special consideration in the field of toxicology as fetal exposure to NPs might be associated with reduced fetal growth and embryotoxicity [16-19]. NPs uptake and transport across the placental barrier has been reported to be dependent on the surface chemistry, size, and the chemical composition of the NPs [20,21]. To date, several alternative in vitro and ex vivo models have been developed and used to study the transport of NPs across the human placental barrier, i.e. ex vivo placental perfusion and in vitro models using primary cells, and cell lines [18, 22, 23]. BeWo b30 placental cell layer has been used as a model to study the barrier for maternal-fetal exchange $[24,25]$. This model is considered an easy and robust screening method to predict the placental transfer of xenobiotics, nutrients, compounds, and NPs [26$28]$. The BeWo b30 cells form a polarized cell layer and express placental differentiation markers [27, 29-31]. Additionally, the BeWo b30 cell layer model has been optimized for nanoparticle transport studies using fluorescent polystyrene NPs (PSNPs) [16]. The human silver concentration in blood is usually below $1 \mu \mathrm{g} / \mathrm{L}$, but can reach levels of up to $194 \mu \mathrm{g} / \mathrm{L}$ in individuals with a compromised skin treated with silver containing creams [32-34]. In our in vitro study we exposed layers of BeWo b30 cells to a AgNP concentration of $1 \mathrm{mg} / \mathrm{L}$.

Combining the BeWo cell layer model with the EST has proven to be a way to predict relative in vivo developmental toxicity [35-37]. The EST has been validated by the European Centre for the Validation of Alternative Methods (ECVAM) [38, 39], where the differentiation of the mouse embryonic stem cells ( $\mathrm{mESCs}$ ) into beating cardiomyocytes is representing the early stages of embryonic development $[40,41]$. Only few studies used the EST to examine the developmental toxicity of AgNPs [41].

This study aims to determine the potential prenatal developmental toxicity of pristine AgNPs with different surface chemistries compared to the 'aged' AgNPs and $\mathrm{AgNO}_{3}$. For this, a combination of the BeWo b30 placental transfer model and the EST was used. Uptake/association and transport of ionic silver and AgNPs across the placental cell layer were determined using inductively coupled plasma mass spectrometry (ICP-MS) and single particle (sp) ICP-MS, respectively. Confocal imaging was used to assess cellular penetration of AgNPs into the differentiated cardiomyocytes.

\section{Results \\ Physicochemical characterization of the AgNPs suspensions and $\mathrm{AgNO}_{3}$ solution}

Four AgNPs were used in this study: lipoic acid-coated (LA), citrate-coated (Cit), branched polyethyleniminecoated (BPEI) AgNPs, and silver sulfide nanoparticles $\left(\mathrm{Ag}_{2} \mathrm{~S}\right)$ NPs that are regarded as aged AgNPs [10]. The hydrodynamic sizes of all the AgNPs were measured in nano-pure water at room temperature using DLS (Table 1). Only the (BPEI) AgNPs were positively charged, while the other AgNPs were negatively charged. All the AgNPs suspensions and the $\mathrm{AgNO}_{3}$ solution, prepared in $\mathrm{DMEM}^{+}$, were analyzed immediately after

Table 1 Physicochemical characteristics of AgNPs

\begin{tabular}{|c|c|c|c|c|c|}
\hline & \multirow{2}{*}{$\begin{array}{l}\text { Size } \\
\text { (TEM) } \\
\mathrm{nm} \pm \\
\mathrm{SD}^{\mathrm{a}, \mathrm{c}}\end{array}$} & \multirow{2}{*}{$\begin{array}{l}\text { Hydrodynamic } \\
\text { size (DLS) } \\
\mathrm{nm} \pm S D^{\mathrm{a}}\end{array}$} & \multirow{2}{*}{$\begin{array}{l}\zeta- \\
\text { potential } \\
(\mathrm{mV}) \pm \\
\mathrm{SD}^{\mathrm{a}, \mathrm{c}}\end{array}$} & \multicolumn{2}{|c|}{ Dissolution (\%) $\pm S D^{b}$} \\
\hline & & & & $\mathrm{Oh}$ & $120 \mathrm{~h}$ \\
\hline (LA) AgNPs & $51 \pm 5$ & $70 \pm 8$ & $-54 \pm 3$ & $15 \pm 4$ & $32 \pm 2^{\#}$ \\
\hline (Cit) AgNPs & $48 \pm 5$ & $61 \pm 5$ & $-46 \pm 1$ & $25 \pm 3$ & $31 \pm 1$ \\
\hline (BPEI) AgNPs & $47 \pm 5$ & $62 \pm 1$ & $+73 \pm 1$ & $17 \pm 1$ & $29 \pm 2^{\#}$ \\
\hline $\mathrm{Ag}_{2} \mathrm{~S} N P S$ & $28 \pm 20$ & $201 \pm 28$ & $-22 \pm 1$ & $31 \pm 1$ & $25 \pm 6$ \\
\hline $\mathrm{AgNO}_{3}$ & - & - & - & - & - \\
\hline
\end{tabular}

${ }^{\mathrm{a}}$ Measured in nano-pure water

${ }^{\mathrm{b}}$ Measured in complete cell culture medium $\left(\mathrm{DMEM}^{+}\right)$

c Provided by Nanocomposix Inc.

\# Significant difference between 0 and $120 \mathrm{~h}$ incubation within the same AgNPs ( $p$-value <0.05) 
preparation to quantify the total silver content and the fraction of silver in particulate form using ICP-MS and spICP-MS, respectively (Figure S1). In addition, sp-ICPMS was used to characterize the suspensions of AgNP, the results are presented in Fig. 4 and explained along with the results of the transport study across the layer of BeWo cells. The sp-ICP-MS characterization in the cell culture medium used for the EST can be found in the supplementary information (Figure S2).

Upon preparing the $(1 \mathrm{mg} / \mathrm{L})$ AgNPs suspensions and $\mathrm{AgNO}_{3}$ solution $(t=0)$, the percentages of dissolution of (LA), (Cit), and (BPEI) AgNPs in the $\mathrm{DMEM}^{+}$were between 15 and 25\%, while in the $\mathrm{Ag}_{2} \mathrm{~S}$ NPs suspension it was $31 \%$. The $\mathrm{AgNO}_{3}$ solution did not contain detectable levels of AgNPs. The dissolution of the AgNPs in $\mathrm{DMEM}^{+}$was measured following a maximal incubation of $120 \mathrm{~h}$ which represents the total exposure time in the mESCs differentiation assay (Table 1). For the (LA) and (BPEI) AgNPs suspensions, the percentage of dissolution of AgNPs increased over these $120 \mathrm{~h}$ by $\sim 2$ fold, while for (Cit) AgNPs and $\mathrm{Ag}_{2} \mathrm{~S}$ NPs no significant difference in the percentage of dissolved AgNPs between the two time points was detected (Table 1).

\section{Cytotoxicity assessment of AgNPs and $\mathrm{AgNO}_{3}$ in $\mathrm{BeWo}$ b30 cells}

The viability of BeWo b30 placental cells was assessed upon 24 $\mathrm{h}$ exposure to a concentration series of AgNPs suspensions or $\mathrm{AgNO}_{3}$ solutions (Fig. 1). Exposure to $\mathrm{AgNO}_{3}$ showed the highest cytotoxicity with an $\mathrm{IC}_{50}$ of $2 \mathrm{mg} / \mathrm{L}$, while exposure to $\mathrm{Ag}_{2} \mathrm{~S}$ NPs resulted in substantially less cytotoxicity with an $\mathrm{IC}_{50}>100 \mathrm{mg} / \mathrm{L}$ (Table 2).
For the subsequent BeWo b30 cell layer exposure studies, a non-toxic concentration of the AgNPs was used (1 $\mathrm{mg} / \mathrm{L}$ ). Following the $24 \mathrm{~h}$ exposure to $1 \mathrm{mg} / \mathrm{L}$ for $\mathrm{AgNO}_{3}$, the cell viability was decreased to $67 \%$.

\section{Cellular uptake/association and transport of AgNPs and $\mathrm{AgNO}_{3}$ through the BeWo b30 placental barrier}

For the uptake/association and transport studies cell layer of BeWo b30 placental cells were used after 6 days of differentiation. Good integrity was confirmed by TEER values ranging between 80 and $100 \Omega . \mathrm{cm}^{2}$ (as defined by others [31]) and low transport values of three paracellular transport marker compounds (i.e. 8, 6, 7\% for LY, and 4 $\mathrm{kDa}$ and $10 \mathrm{kDa}$ FITC-dextrans, respectively).

The BeWo b30 cell layer were exposed for 4, 6, 18, and $24 \mathrm{~h}$ to $1 \mathrm{mg} / \mathrm{L}$ of the different AgNPs suspensions, or the $\mathrm{AgNO}_{3}$ solution. The silver content in the media from the apical, cellular and basolateral compartments was quantified using ICP-MS measurements at all exposure times and expressed as total $\mathrm{Ag}$ (i.e. ionic silver and particulate silver; Fig. 2). In addition, the silver fraction as AgNPs was quantified using sp-ICP-MS measurements, but only after $24 \mathrm{~h}$ exposure (Fig. 3). The TEER measurements performed after the exposure to the AgNPs and $\mathrm{AgNO}_{3}$ indicated that the BeWo b30 barrier integrity was not affected.

The total Ag content in the apical compartment declined significantly in a time-dependent manner in the (LA), (Cit), (BPEI) AgNPs and $\mathrm{AgNO}_{3}$ exposure groups (Fig. 2a). In the $\mathrm{Ag}_{2} \mathrm{~S}$ NPs exposure group, the total $\mathrm{Ag}$ content of the apical compartment declined rapidly at early time points but remained stable from $4 \mathrm{~h}$ exposure

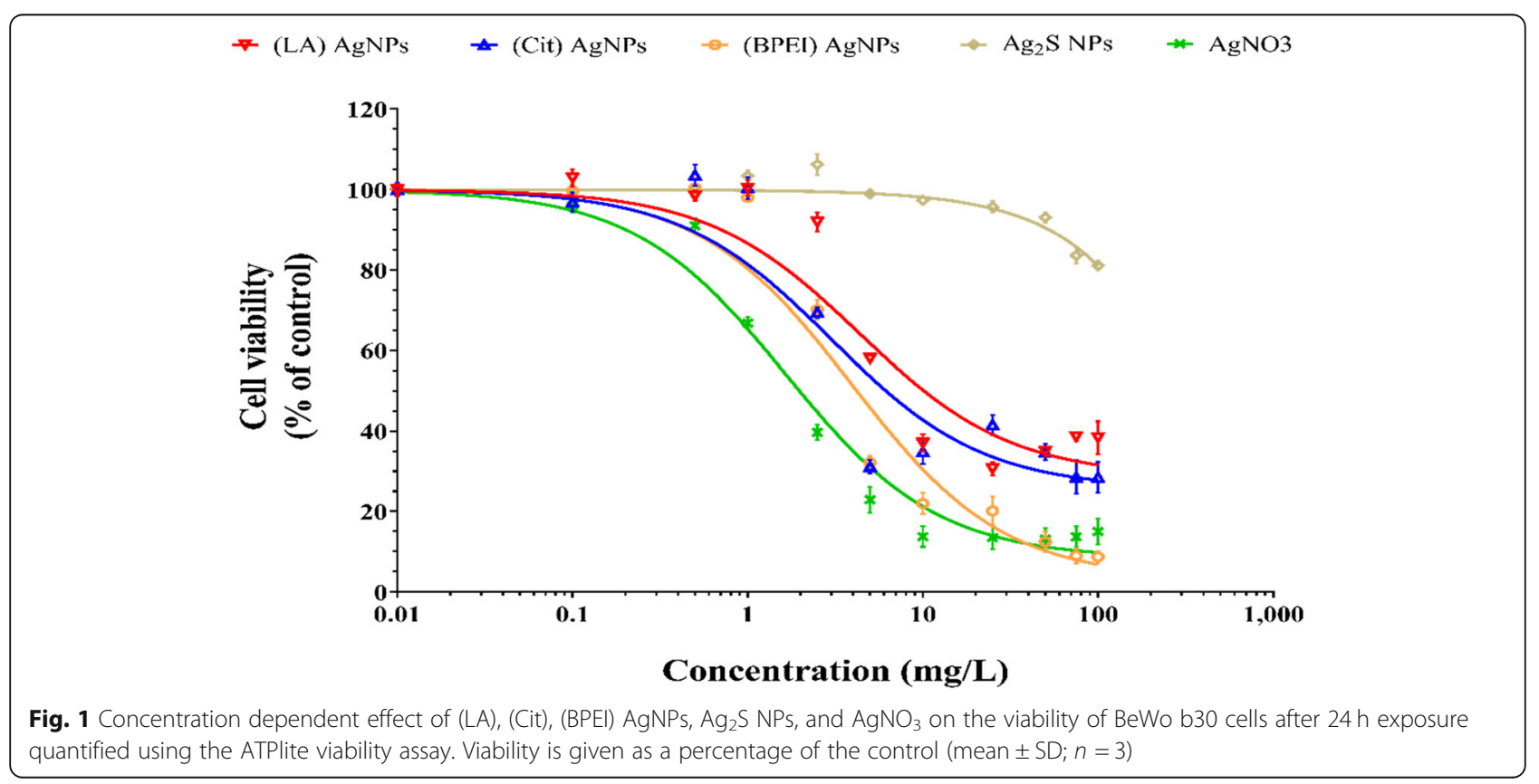


Table 2 The $\mathrm{IC}_{50}$ values of AgNPs and $\mathrm{AgNO}_{3}$ in $\mathrm{BeWo}$ b30 placental cells after $24 \mathrm{~h}$ exposure

\begin{tabular}{ll}
\hline Treatment & $I C_{50}(\mathrm{mg} / \mathrm{L})$ \\
\hline$(\mathrm{LA})$ AgNPs & 11 \\
(Cit) AgNPs & 6.2 \\
(BPEI) AgNPs & 4.3 \\
$\mathrm{Ag}_{2} \mathrm{~S} \mathrm{NPS}$ & $>100$ \\
$\mathrm{AgNO}_{3}$ & 2 \\
\hline
\end{tabular}

$\mathcal{I C}_{50}$ the concentration where $50 \%$ of BeWo b30 cells are viable

onwards. This early decline was significantly larger compared to the decline observed for the other AgNPs. The fractions of total Ag present as AgNPs in the apical compartments upon $24 \mathrm{~h}$ exposure to (LA), (Cit), (BPEI) AgNPs, and $\mathrm{Ag}_{2} \mathrm{~S}$ NPs were comparable (Fig. 3a; Table 3). The fraction of AgNPs was lower for the $\mathrm{AgNO}_{3}$ group.

For the cellular compartment of the BeWo b30 cell model, the total Ag content increased significantly in a timedependent manner for the (LA), (Cit) and (BPEI) AgNPs, except for the $6 \mathrm{~h}$ time point where the increase versus the $4 \mathrm{~h}$ time point was not statistically significant (Fig. 2b). While the time-dependent increase in the total $\mathrm{Ag}$ content was less pronounced upon exposure to $\mathrm{Ag}_{2} \mathrm{~S}$ NPs or $\mathrm{AgNO}_{3}$, the total Ag concentration in the cellular compartment increased significantly after $24 \mathrm{~h}$ exposure compared to that observed after 4 and $6 \mathrm{~h}$ exposure. In the cellular compartment, the concentration of AgNPs upon $24 \mathrm{~h}$ exposure to (BPEI) AgNPs was higher compared to what was observed following exposure to the other AgNPs and $\mathrm{AgNO}_{3}$ (Fig. 3b). However, upon expressing the AgNPs concentrations in the cellular compartment after $24 \mathrm{~h}$ exposure as percentages of the total Ag present in the cellular compartments, these percentages between (LA), (Cit), and (BPEI) AgNPs were comparable. Upon exposure to $\mathrm{Ag}_{2} \mathrm{~S}$ NPs, the cellular compartment contained a lower percentage of AgNPs (Fig. 3b, Table 3). The cellular compartment exposed to $\mathrm{AgNO}_{3}$ contained only $4 \%$ of AgNPs of the total Ag content in this compartment (Fig. 3b, Table 3).

In spite of the time-dependent decrease in the amount of total $\mathrm{Ag}$ in the apical compartment and an increase in the amount of total Ag in the cellular compartment (Fig. 2a and b), no time-dependent transport of total Ag across the cell layer to the basolateral compartment was observed upon exposure to all the AgNPs, apart from incidental significant differences for the (Cit) AgNPs (Fig. 2c). Upon $\mathrm{AgNO}_{3}$ exposure, the total $\mathrm{Ag}$ content in the basolateral compartment showed a time-dependent increase. Additionally, AgNPs were detected in the basolateral compartment. The highest percentage of AgNPs from the total Ag content was detected in the basolateral compartments exposed to the (LA) AgNPs followed by (Cit) and (BPEI) AgNPs and $\mathrm{Ag}_{2} \mathrm{~S}$ NPs (Fig. 3c and Table 3). Following exposure to $\mathrm{AgNO}_{3}$ only $2 \%$ of the compartment's total Ag content was present as AgNPs.

\section{Size distribution of AgNPs before and after BeWo b30 exposure}

The size distributions of the AgNPs were assessed in the different compartments (apical, cellular, and basolateral) of the BeWo b30 model. The sp-ICP-MS data were transformed into size distribution plots depicting the number of particles corresponding to the size, clustered in $5 \mathrm{~nm}$ diameter clusters (Fig. 4). The size distributions of the (LA), (Cit), and (BPEI) AgNPs exposure suspensions were comparable, with median particle sizes of 50 , 45 , and $45 \mathrm{~nm}$, respectively (Fig. $4 \mathrm{a}, \mathrm{b}$ and c). The size distribution of $\mathrm{Ag}_{2} \mathrm{~S}$ NPs suspension demonstrated a right-skewed size distribution with a median particle size of $35 \mathrm{~nm}$ (Fig. 4d). No AgNPs were detected in the $\mathrm{AgNO}_{3}$ solution (Fig. 4e).

After 24 $\mathrm{h}$ exposure, the total number of AgNPs that was detected in the apical compartments decreased for all four AgNPs (Fig. 4f-i) where the (BPEI) AgNPs (Fig. 4h) showed the largest decrease. The size distributions of all the AgNPs in the apical compartment were right skewed. The size distributions of (LA) and (Cit) AgNPs were the least affected with a median size of 45 and 40 $\mathrm{nm}$, respectively (Fig. $4 \mathrm{f}$ and g). The size distribution of both the (BPEI) AgNPs and $\mathrm{Ag}_{2} \mathrm{~S}$ NPs indicated an increased median size of $70 \mathrm{~nm}$ and $50 \mathrm{~nm}$, respectively, indicating agglomeration of the particles. (Fig. $4 \mathrm{~h}$ and i). Some AgNPs were detected in the $\mathrm{AgNO}_{3}$ sample with a median size of $30 \mathrm{~nm}$ (Fig. 4j).

The size distributions of all AgNPs in the cellular compartments were also right skewed. This was more pronounced than in the apical compartments for the (LA) and (Cit) AgNPs (Fig. 4k and l), with median sizes of 50 and $45 \mathrm{~nm}$, respectively. It was less pronounced for the (BPEI) AgNPs and $\mathrm{Ag}_{2} \mathrm{~S}$ NPs (Fig. $4 \mathrm{~m}$ and $\mathrm{n}$ ), with median sizes of $40 \mathrm{~nm}$ and $35 \mathrm{~nm}$, respectively. The AgNPs that were detected in the cellular compartment upon exposure to $\mathrm{AgNO}_{3}$ had a median size of $40 \mathrm{~nm}$ (Fig. 4o).

The size distributions of all AgNPs in the basolateral compartments were right skewed and were very similar in shape but different in number of particles. The (LA) and (Cit) AgNPs were less right skewed than in the cellular compartments and had median sizes of 50 and $40 \mathrm{~nm}$, respectively (Fig. 4p and q). The size distribution curve of (BPEI) AgNPs was very wide, with a median size of $45 \mathrm{~nm}$ (Fig. 4r). The $\mathrm{Ag}_{2} \mathrm{~S}$ NPs had a median size of $45 \mathrm{~nm}$ and featured a size distribution pattern very similar to that in the starting suspension (Fig. $4 \mathrm{~s}$ and d). For $\mathrm{AgNO}_{3}$, AgNPs with median size of $35 \mathrm{~nm}$ were detected (Fig. 4t).

\section{In vitro developmental toxicity assessment of AgNPs and $\mathrm{AgNO}_{3}$}

To assess the potential in vitro developmental toxicity of AgNPs and $\mathrm{AgNO}_{3}$, the EST was employed. First, the viability of the mESCs was assessed upon 24 and $120 \mathrm{~h}$ 


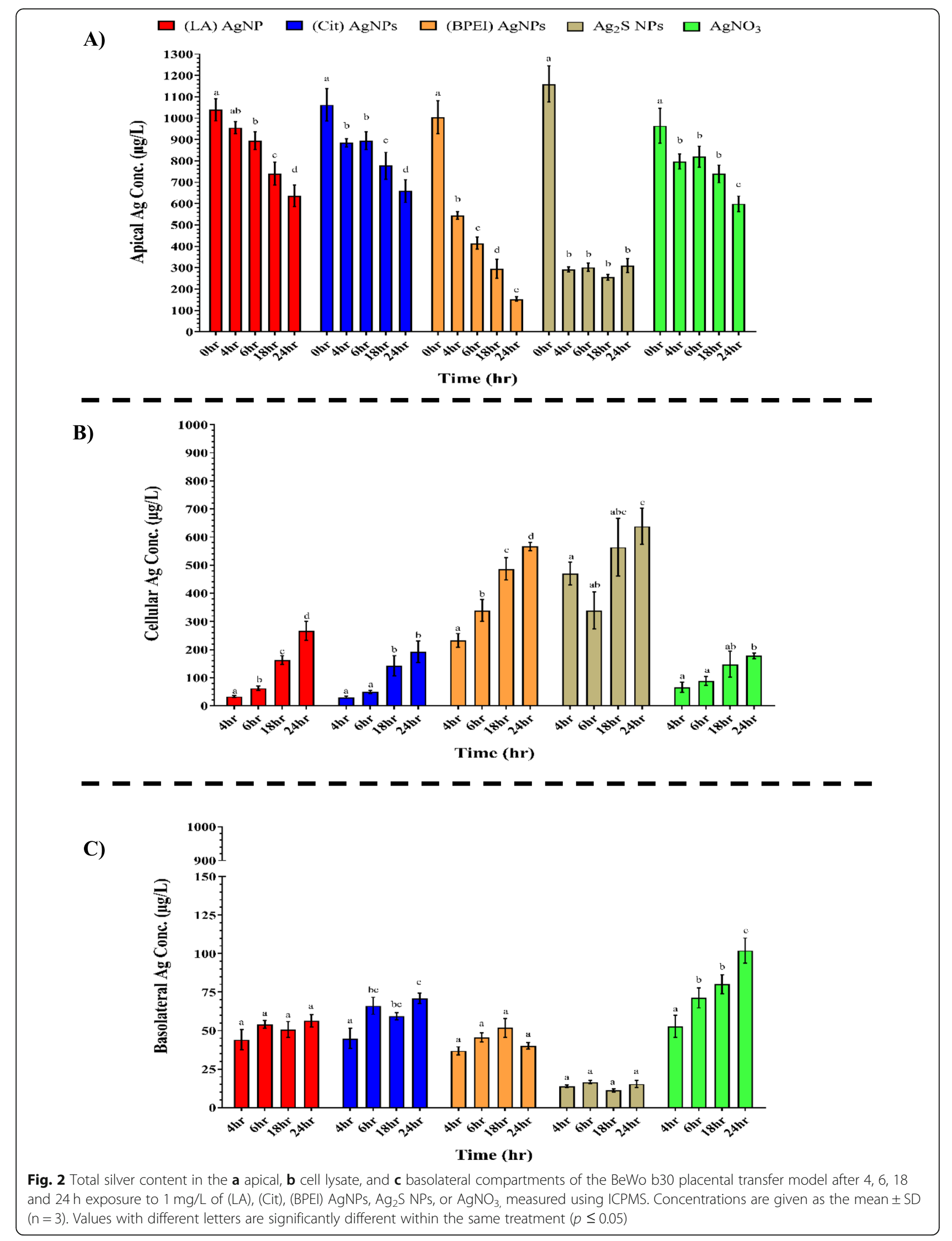




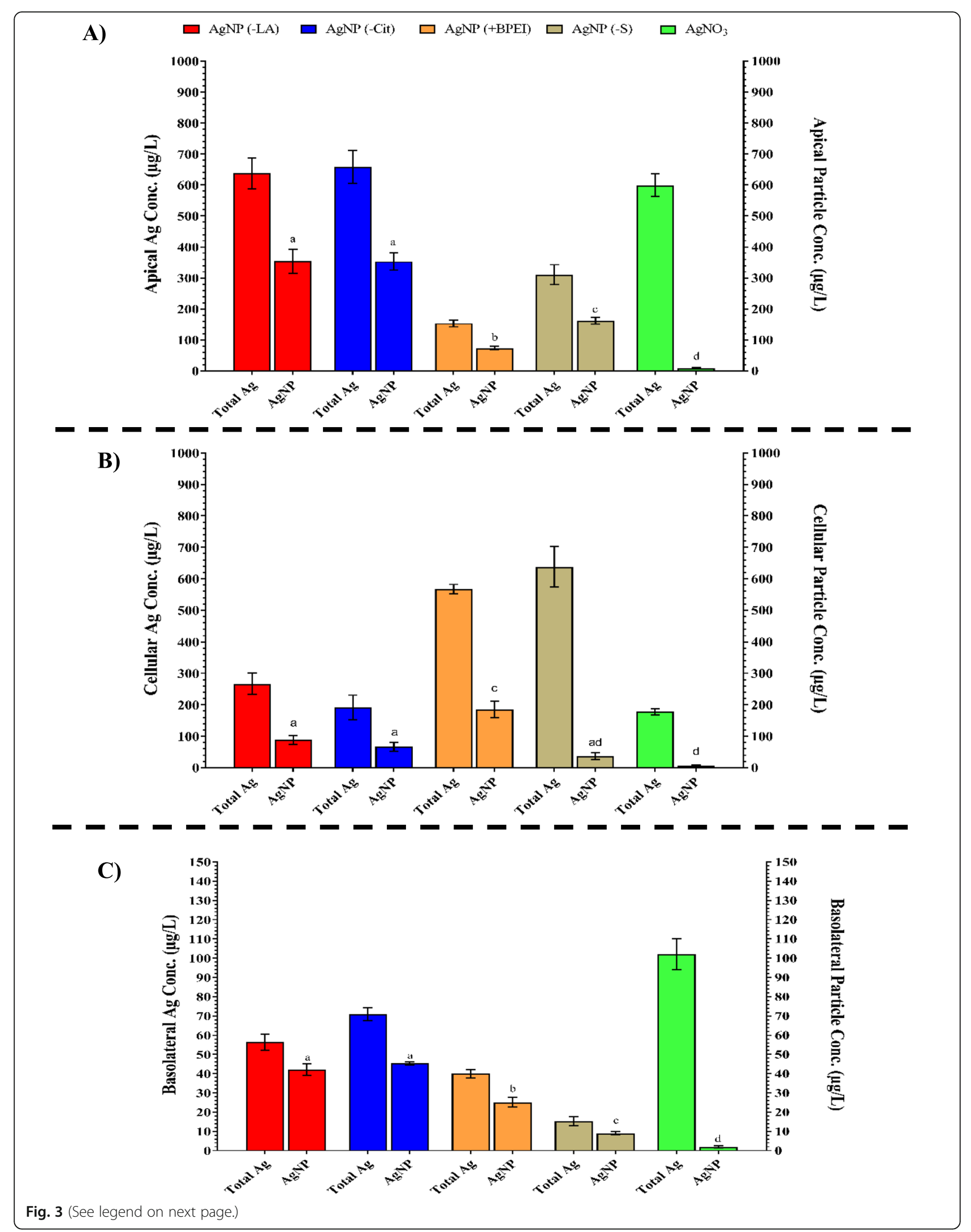


(See figure on previous page.)

Fig. 3 Total silver content (on the left axis) versus the AgNPs content (mass-based on the right axis) in the $\mathbf{a}$ apical, $\mathbf{b}$ cell lysate, and $\mathbf{c}$ basolateral compartments of the BeWo b30 placental transfer model after $24 \mathrm{~h}$ exposure to $1 \mathrm{mg} / \mathrm{L}$ of (IA), (Cit), (BPEl) $\mathrm{AgNPs}_{1} \mathrm{Ag}_{2} \mathrm{~S} N \mathrm{NP}$, or $\mathrm{AgNO}_{3}$, measured using splCP-MS. Concentrations are given as the mean $\pm \mathrm{SD}(\mathrm{n}=3)$. Values with different letters are significantly different within the same treatment $(p \leq 0.05)$

exposure to a concentration series of $\mathrm{AgNPs}$ and $\mathrm{AgNO}_{3}$ using the ATPlite assay (Fig. 5). The $\mathrm{Ag}_{2} \mathrm{~S}$ NPs showed lowest toxicity after 24 and $120 \mathrm{~h}$ exposure with an $\mathrm{IC}_{50}$ of $>100$ and $29 \mathrm{mg} / \mathrm{L}$, respectively, while $\mathrm{AgNO}_{3}$ showed the highest toxicity after 24 and $120 \mathrm{~h}$ exposure with an $\mathrm{IC}_{50}$ of 25 and $0.33 \mathrm{mg} / \mathrm{L}$, respectively (Table 4). All tested AgNPs and $\mathrm{AgNO}_{3}$ induced a concentration-dependent reduction in viability of the $\mathrm{mESCs}$ with higher cytotoxicity after $120 \mathrm{~h}$ compared with $24 \mathrm{~h}$ exposure.

Subsequently, the potential inhibitory effects of AgNPs and $\mathrm{AgNO}_{3}$ on the differentiation of mESCs into contracting cardiomyocytes was studied. Except for the $\mathrm{Ag}_{2} \mathrm{~S}$ NPs, all tested AgNPs and $\mathrm{AgNO}_{3}$ induced a concentration-dependent inhibition of the differentiation of the mESCs into contracting cardiomyocytes (Fig. 5). The (BPEI) AgNPs were the most potent to inhibit the differentiation of mESCs with an $\mathrm{ID}_{50}$ of $8 \mathrm{mg} / \mathrm{L}$ The $\mathrm{AgNO}_{3}$, (LA) and (Cit) AgNPs had $\mathrm{ID}_{50}$ of 9.5, 13 and $16 \mathrm{mg} / \mathrm{L}$, respectively, while the $\mathrm{ID}_{50}$ of $\mathrm{Ag}_{2} \mathrm{~S}$ NPs was > $100 \mathrm{mg} / \mathrm{L}$ (Table 3). For all $\mathrm{AgNPs}$ and $\mathrm{AgNO}_{3}$, the inhibitory effects on the mESCs differentiation were observed at higher concentrations than those associated with the decrease in $\mathrm{mESCs}$ viability after $120 \mathrm{~h}$ exposure, as indicated by a higher $\mathrm{ID}_{50}$ than $\mathrm{IC}_{50}$. This indicates that effects on $\mathrm{mESCs}$ differentiation are likely due to cytotoxicity. In order to estimate the influence of $\mathrm{Ag}$ ions, released from dissolving AgNPs, on the mESCs differentiation we interpolated the concentration of $\mathrm{Ag}$ ions present at the $\mathrm{ID}_{50}$ for each AgNPs (Table 3). The concentration of $\mathrm{Ag}$ ions present at the $\mathrm{ID}_{50}$ was estimated to account for 16,23 , and $31 \%$ of the observed inhibition of the mESCs differentiation upon exposure to (BPEI),

Table 3 The fraction of AgNPs as \% of total Ag content in the apical, cellular and basolateral compartments of the BeWo b30 placental cell model after $24 \mathrm{~h}$ exposure as calculated from the data presented in Fig. 3

\begin{tabular}{llll}
\hline Treatment & \multicolumn{2}{l}{ Compartment } & \\
\cline { 2 - 4 } & Apical & Cellular & Basolateral \\
\hline (LA) AgNPs & $55 \%$ & $33 \%{ }^{*}$ & $77 \%^{*} \#$ \\
(Cit) AgNPs & $54 \%$ & $35 \%{ }^{*}$ & $64 \%{ }^{*}$ \\
(BPEI) AgNPs & $52 \%$ & $32 \%{ }^{*}$ & $63 \%{ }^{\#}$ \\
$\mathrm{Ag}_{2} \mathrm{~S} \mathrm{NPs}$ & $48 \%$ & $6 \%{ }^{*}$ & $59 \%{ }^{\#}$ \\
$\mathrm{AgNO}_{3}$ & $2 \%$ & $4 \%{ }^{*}$ & $2 \%$
\end{tabular}

* Significant difference compared to the apical compartment of the same exposure group ( $p$-value $<0.05$ )

\# Significant difference between cell and basolateral compartments of the same exposure group ( $p$-value $<0.05)$
(LA), and (Cit) AgNPs at their $\mathrm{ID}_{50}$, respectively. In case of $\mathrm{Ag}_{2} \mathrm{~S}$ NPs, no inhibition of the mESCs was found up to the highest concentration tested of the $\mathrm{Ag}_{2} \mathrm{~S}$ NPs. Confocal imaging demonstrated that AgNPs were internalized into the differentiated cardiomyocytes. AgNPs were mainly localized in the cytoplasm and to some extent in the nucleus (Fig. 6).

\section{Discussion}

This study aimed to investigate the potential prenatal developmental toxicity of pristine AgNPs with different surface chemistries and of aged $\mathrm{Ag}_{2} \mathrm{~S}$ NPs. For this, we combined the BeWo b30 placental transport model with the EST. This enabled us to evaluate the potential fetal exposure to AgNPs and to study the likelihood of AgNPs to induce in vitro developmental toxicity.

\section{The interaction of ag and AgNPs with BeWo b30 placental cells}

Exposure to the (LA), (Cit), and (BPEI) AgNPs and $\mathrm{AgNO}_{3}$ showed a concentration-dependent decrease in BeWo b30 cell viability. The positively charged (BPEI) coated AgNPs were more toxic, especially at concentrations higher than $1 \mathrm{mg} / \mathrm{L}$, compared to the negatively charged (LA) and (Cit) coated AgNPs. In line with this observation, higher cytotoxicity for positively charged versus negatively charged NPs in BeWo b30 cells has been reported previously for polystyrene NPs [42]. Additionally, it has been reported that oleate coated ferric oxide NPs were more toxic to BeWo b30 cells than uncoated ones [26], indicating that both the surface charge and surface chemistry can cause differences in toxicity.

Exposure of the placental BeWo cell layer to $1 \mathrm{mg} / \mathrm{L}$ of (LA), (Cit), (BPEI) AgNPs, and $\mathrm{AgNO}_{3}$ for different durations resulted in a time-dependent increase of total $\mathrm{Ag}$ in the cellular compartments. The transport of silver across the placental cell layer was favorable as ionic silver rather than particulate, which was similarly reported using the ex vivo human placental perfusion model where the transport of ionic silver was 10-fold higher than that of particulates [43].

The spICP-MS measurements after $24 \mathrm{~h}$ exposure to the different AgNPs showed the presence of AgNPs in the cellular and basolateral compartments. The surface chemistry of the AgNPs significantly affected the detected concentration of AgNPs in the cellular compartment where the highest concentrations of AgNPs were observed following exposure to (BPEI) AgNPs followed by (LA) AgNPs, (Cit) AgNPs and $\mathrm{Ag}_{2} \mathrm{~S}$ NPs. A comparable effect of the surface chemistry of NPs on the 


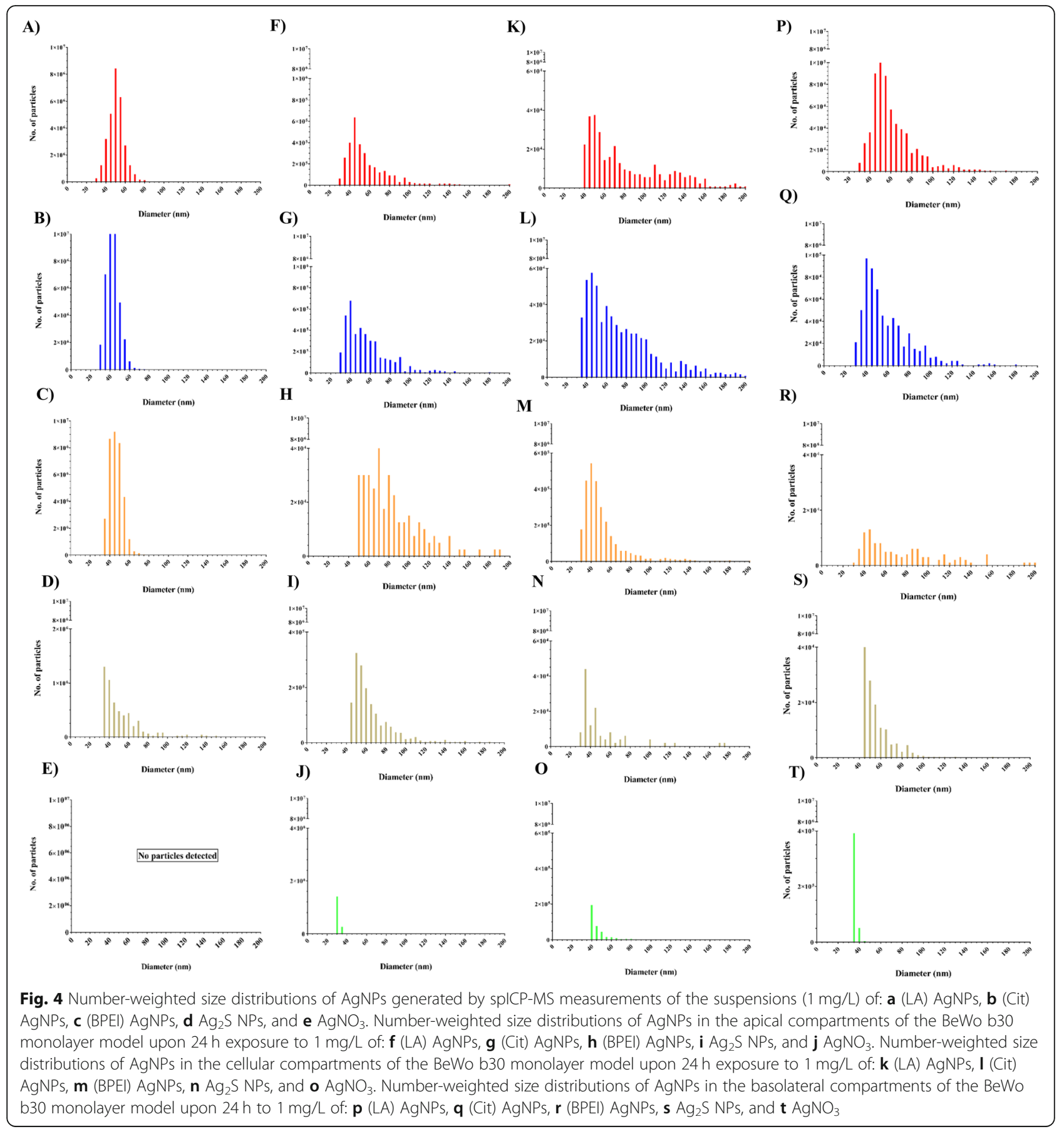

cellular uptake/association was also reported for ferric oxide NPs where oleate coated NPs were significantly lower associated with the BeWo cell layer than uncoated NPs [26]. Besides, the cellular compartment contained a lower AgNPs percentage (of the total Ag content) compared to the AgNPs percentage in the exposure concentration in the apical compartment. This suggests a preference towards cellular uptake/association of ionic silver over AgNPs or possible dissolution of the AgNPs cellularly following their uptake [44-46].
In the basolateral compartments of all the exposure groups, AgNPs were detected. In general, the AgNPs percentage (of the total Ag content) in the basolateral compartment was higher than the AgNPs percentage (of the total Ag content) in the cellular compartment. This could suggest a preference towards cellular excretion of AgNPs over ionic silver. Also, the AgNPs measured could result from de novo formation of AgNPs from ionic silver that might reflect a tendency of the ionic silver to form 

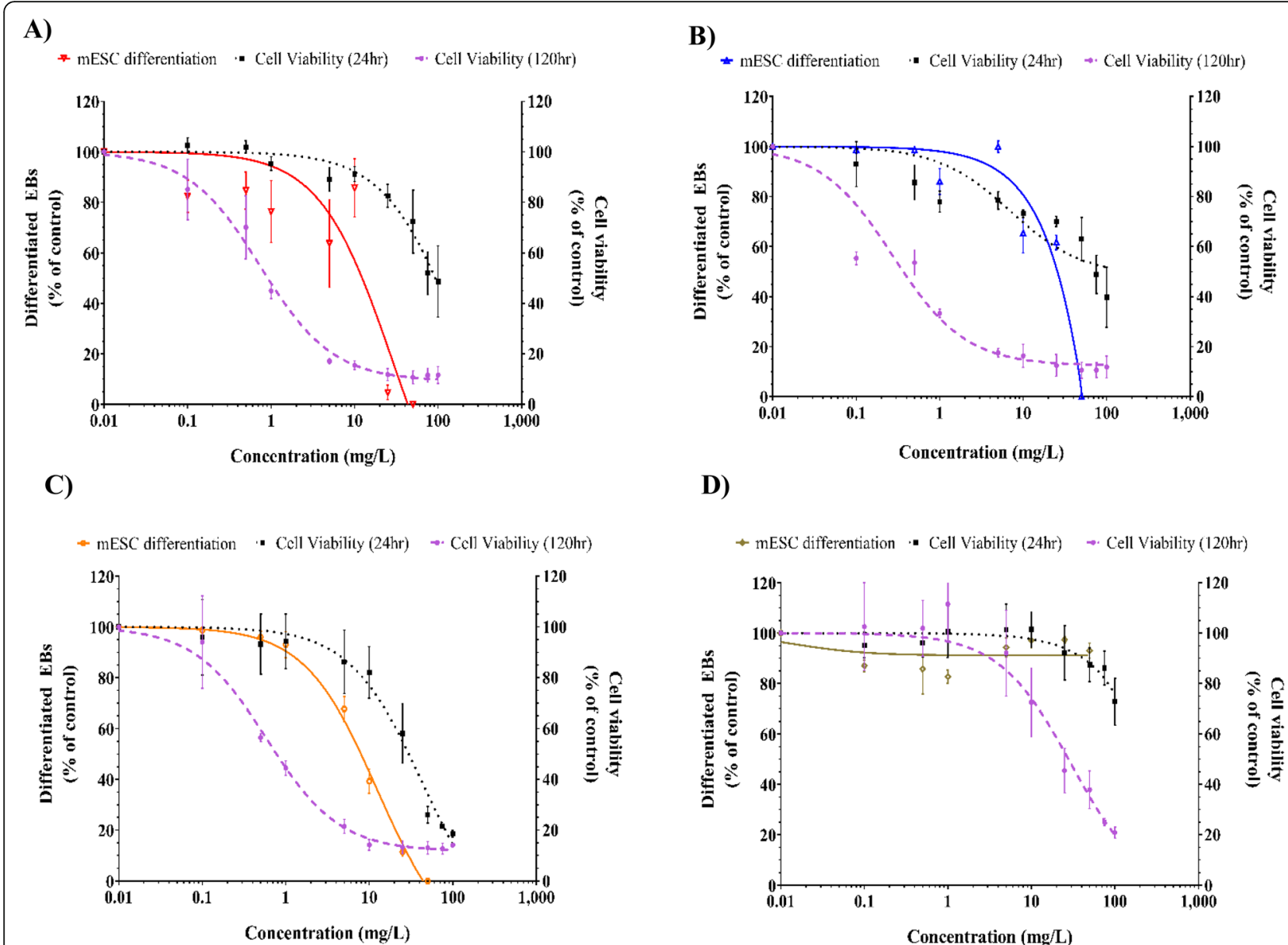

D)

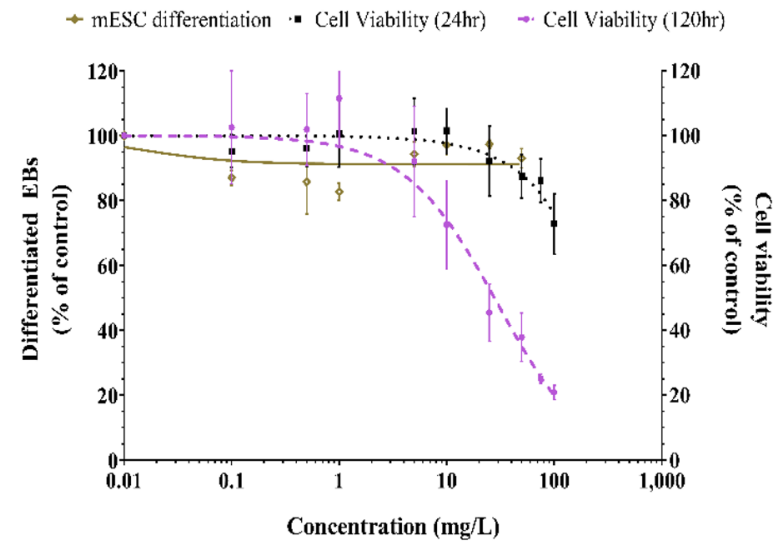

E)

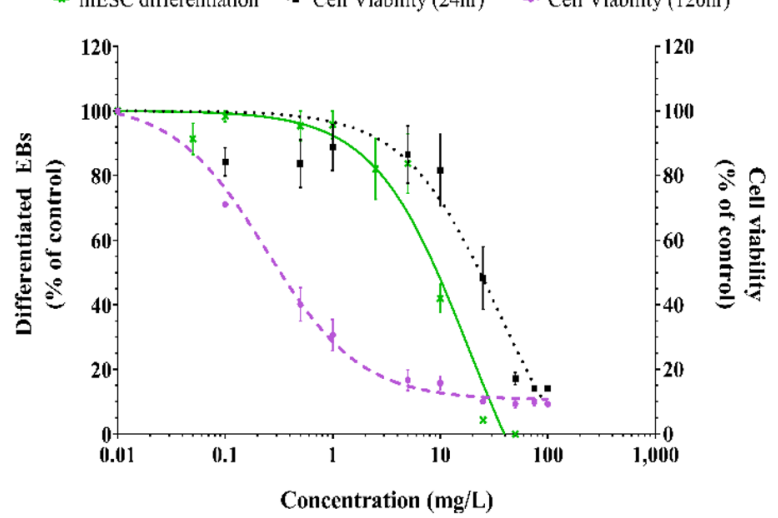

Fig. 5 Concentration-response curves for cytotoxicity towards mESCs and for the effect on differentiation into contracting cardiomyocytes of: a (LA) AgNPs, b (Cit) AgNPs, c (BEPI) AgNPs, d ( $\left.\mathrm{Ag}_{2} \mathrm{~S}\right) \mathrm{NPs}$, and $\mathbf{e} \mathrm{AgNO}_{3}$. The viability of mESCs (right $y$-axis) was assessed using the ATPlite assay after $24 \mathrm{~h}$ and $120 \mathrm{~h}$ of exposure. The differentiation of mESCs into contracting cardiomyocytes (left $y$-axis) was scored after microscopical evaluation. Values are given as a percentage of the control (mean $\pm S D ; n=3$ )

these new particles in the cell culture medium more than the cellular environment. This later scenario is likely to happen taking into consideration the presence of AgNPs in all compartments upon exposure to $\mathrm{AgNO}_{3}$.
Contribution of surface chemistry of AgNPs on transport across a layer of BeWo cells

The surface chemistry of the AgNPs significantly affected the detected concentration of AgNPs also in the basolateral compartment where the highest concentrations of 
Table 4 The $\mathrm{IC}_{50}$ and $\mathrm{ID}_{50}$ of AgNPs and $\mathrm{AgNO}_{3}$ after 24 and $120 \mathrm{~h}$ exposure in mESCs

\begin{tabular}{|c|c|c|c|c|c|}
\hline & $\begin{array}{l}\mathrm{IC}_{50}(\mathrm{mg} / \mathrm{L}) \\
(24 \mathrm{~h})\end{array}$ & $\begin{array}{l}\mathrm{IC}_{50}(\mathrm{mg} / \mathrm{L}) \\
(120 \mathrm{~h})\end{array}$ & $\begin{array}{l}\mathrm{ID}_{50} \\
(\mathrm{mg} / \mathrm{L})\end{array}$ & $\begin{array}{l}\text { Calculated concentration of dissolved } \mathrm{Ag}^{+} \\
(\mathrm{mg} / \mathrm{L}) \text { in } \mathrm{ID}_{50}(120 \mathrm{~h})\end{array}$ & $\begin{array}{l}\text { Calculated } \% \text { of inhibition of differentiation } \\
\text { induced by dissolved } \mathrm{Ag}^{+}\end{array}$ \\
\hline $\begin{array}{l}(\mathrm{LA}) \\
\text { AgNPs }\end{array}$ & 100 & 0.9 & 13 & 4.16 & $22.5 \%$ \\
\hline $\begin{array}{l}\text { (Cit) } \\
\text { AgNPs }\end{array}$ & 100 & 0.38 & 16 & 4.96 & $31 \%$ \\
\hline $\begin{array}{l}\text { (BPEI) } \\
\text { AgNPs }\end{array}$ & 30 & 0.8 & 8 & 2.24 & $16 \%$ \\
\hline $\begin{array}{l}\mathrm{Ag}_{2} \mathrm{~S} \\
\mathrm{NPS}\end{array}$ & $>100$ & 29 & $>100$ & 25 & N.A. \\
\hline $\mathrm{AgNO}_{3}$ & 25 & 0.33 & 9.5 & - & - \\
\hline
\end{tabular}

$I_{50}$ the concentration where $50 \%$ of mESCs are viable

$I D_{50}$ the concentration of $50 \%$ inhibition of differentiation of EBs into beating cardiomyocytes

N.A. Not applicable

AgNPs were observed following exposure to (LA) AgNPs and (Cit) AgNPs followed by (BPEI) AgNPs and $\mathrm{Ag}_{2} \mathrm{~S}$ NPs. The surface chemistry of NPs was reported to play a role in the transport of ferric oxide NPs where the placental transport was significantly higher for oleate coated NPs than uncoated NPs [26]. Also, the placental transport of pegylated AuNPs was reported to be higher than that of sodium carboxylated AuNPs of the same size (Aengenheister et al. 2018a).
Next to the surface chemistry of NPs, their size [20, 23] and composition [24] are also suggested to influence their transport through the placental barrier model. The transport of PSNPs was described to be size dependent, where transport of $50 \mathrm{~nm}$ PSNPs was six times higher than that of $100 \mathrm{~nm}$ PSNPs [16]. The placental transport of AuNPs also showed a size-dependency, where 10 to $30 \mathrm{~nm}$ AuNPs did not cross the placental barrier [47]

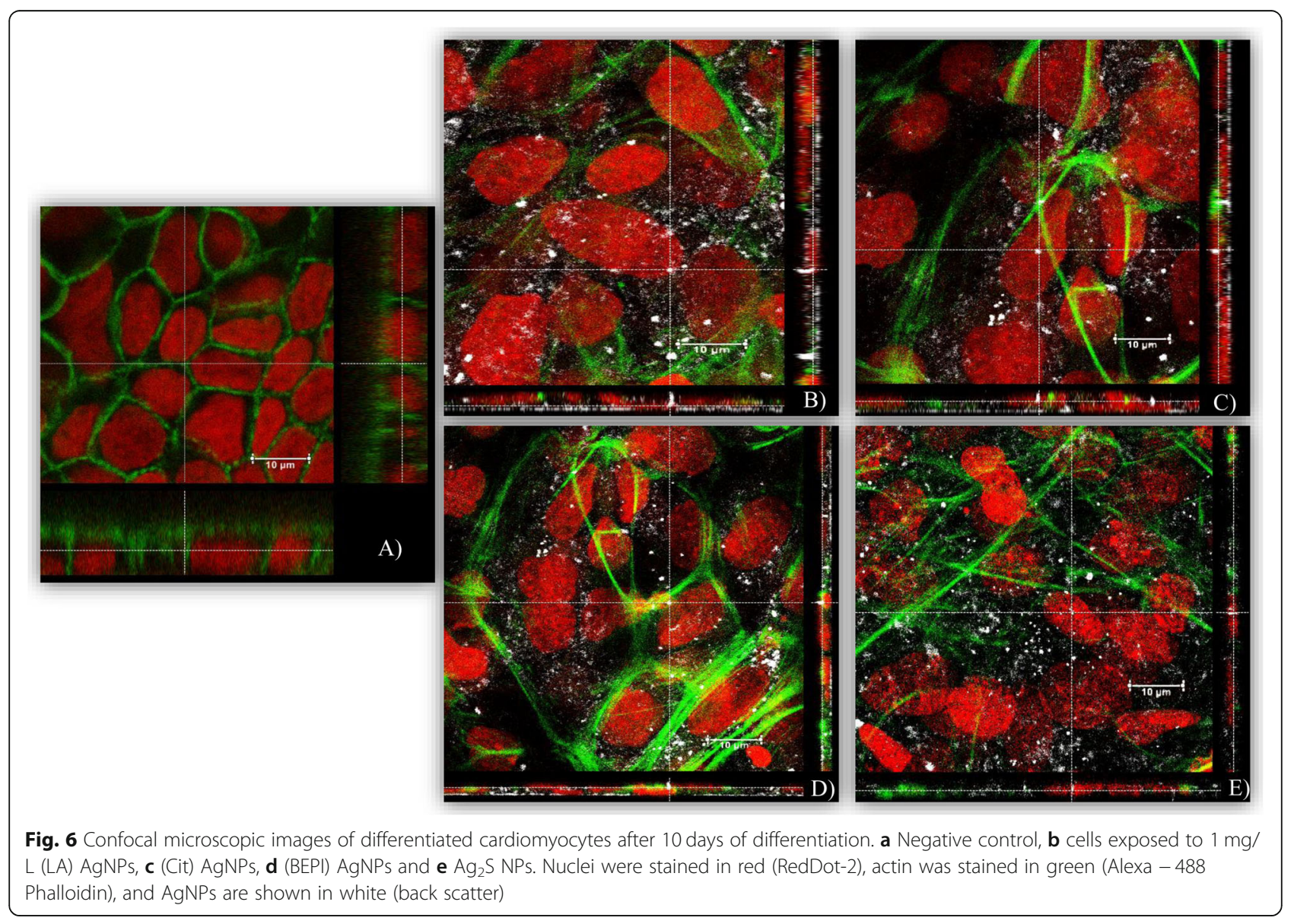


and the smaller 3 and $4 \mathrm{~nm}$ AuNP crossed the placental barrier [21]. Upon the exposure of either the BeWo b30 (up to $24 \mathrm{~h}$ ) or the perfused human placenta (up to $6 \mathrm{~h}$ ) to 25 and $50 \mathrm{~nm}$ silica NPs, no placental transport could be detected [24]. Following exposure of perfused human placenta to AgNPs with different surface chemistries (polyethylene glycol and sodium carboxylate, and a primary size of 7-15 nm) very low translocation has been observed. In the fetal circulation 0.02 to $0.2 \%$ of the administered dose was detected as total silver in the fetal circulation. Only a small mass fraction of this silver was detected in particulate form $(>25 \mathrm{~nm})$. Interestingly, the authors point out that AgNPs in the fetal circulation could originate from de novo formation following ionic $\mathrm{Ag}$ translocation [43]. From the limited number of in vivo studies of placental transport of NPs where pregnant animals were used, AgNPs were found to be able to cross the placental barrier of rats and reach the fetus [48-52]. The study of Fennell et al. reported that $24 \mathrm{~h}$ after intravenous administration to pregnant rats with AgNPs, about 3-4\%, measure as total Ag, of the administered dose was found in the fetus [48]. The transported levels that we observed ranged between 1 and $8 \%$ as total Ag and between 1 and 5\% as AgNPs and are thus in between the observations in rodents and the human placenta perfusion studies.

\section{Potential fetal toxicity following exposure to AgNPs and $\mathrm{AgNO}_{3}$}

Following the capability of the AgNPs and $\mathrm{AgNO}_{3}$ to cross the BeWo b30 cell layer in vitro either as ionic or as particulate silver, induction of adverse outcomes upon reaching the embryo cannot be excluded. We therefore assessed the potential developmental toxicity of the AgNPs using the EST. The EST represents a good tool to measure the developmental toxicity in vitro as it has been validated by ECVAM and it showed a good level of concordance in the in vitro to in vivo comparisons [53, 54]. Combining the EST with the BeWo placental transport model even resulted in an increased predictability of in vivo developmental toxicity of chemicals [37].

Our data from the EST did not point towards potential developmental toxicity because the effects of the AgNPs and $\mathrm{AgNO}_{3}$ on differentiation of mESCs into contracting cardiomyocytes were only observed at cytotoxic concentrations [39]. These result are in line with the observations of Park et al. and Corradi et al. where 7, 20, 80, and $113 \mathrm{~nm}$ AgNPs induced dose-dependent cytotoxicity, and inhibition of $\mathrm{mESCs}$ differentiation only at concentrations higher than the ones associated with cytotoxicity $[53,55]$. Besides, the $\mathrm{IC}_{50}$ values for cytotoxicity of the AgNPs in the mESCs were higher than what would be considered realistic in vivo concentrations as our results from the BeWo b30 transport experiments indicated low transport of AgNPs into the fetal compartment. Additionally, considering the oral route as one of the main exposure routes of the AgNPs, it is important to take into account also their very low transport across the intestinal barrier in vitro $[14,56]$ and in vivo [15] which will consequently lower the concentrations of the AgNPs that might reach the fetus.

\section{Effects following exposure to aged AgNPs}

It is of interest to note that the aged silver sulfide nanoparticles showed a different behavior compared to the pristine AgNPs. Although the dissolution and charge of the $\mathrm{Ag}_{2} \mathrm{~S}$ NPs were comparable to those of the (LA) and (Cit) pristine AgNPs, their effects on the cellular viability of the BeWo cells and their transport across the BeWo call layer were significantly lower. Upon placental exposure to $\mathrm{Ag}_{2} \mathrm{~S}$ NPs, a relatively high concentration of total $\mathrm{Ag}$ in the cellular compartment was detected after $4 \mathrm{~h}$ exposure which remained unchanged upon longer exposure up to $24 \mathrm{~h}$. This was in contrast with the time dependent behavior of the pristine AgNPs. Also, the lowest amount of total Ag, in comparison with the pristine AgNPs, was transported through the placental cell layer, even though the total Ag concentration in the cellular fraction was relatively high in comparison with the pristine AgNPs. Additionally, the aged particles did not induce any inhibition of the mESCs differentiation in the EST. The lower bioavailability of the $\mathrm{Ag}_{2} \mathrm{~S}$ NPs could be explained by the sulfidation processes that these aged particles go through during their formation. The sulfidation of the AgNPs is likely to change the colloidal dynamics of these particles which increases the probability of these particles to aggregate and settle compared to the pristine NPs $[10,57,58]$. Possibly these aggregates bind strongly to the outer cell membrane, leading to high total Ag concentrations in the cellular fractions, but low transport through the cells. Taking these results into account, these aged AgNPs are imposing a very low risk for developmental toxicity. It is important to highlight that this study is one of the first studies that considered the potential hazards of aged AgNPs on the developing human fetus.

\section{Conclusion}

To conclude, the AgNPs tested here were able to transport across BeWo b30 cell layer where the surface chemistry of these AgNPs influenced the amounts of AgNPs transported. The particles detected in the basolateral compartment, could result from transport of the original AgNPs or partly from de novo AgNPs formed from ionic silver that was transported. The observed inhibitory effects of the AgNPs on differentiation of mESCs were most likely the result of cytotoxicity rather than specific effects related to developmental toxicity. The aged AgNPs were significantly less cytotoxic and bioavailable 
and did also not induce in vitro inhibition of differentiation of mESCs. The combination of the BeWo placental transport model with the mESCs differentiation assay is considered a valuable alternative in vitro methodology for prenatal developmental toxicity screening and prioritization of silver nanoparticles.

\section{Methods}

\section{Nanoparticles and chemicals}

Negatively charged $20 \mathrm{~nm}$ 'aged' silver sulfide nanoparticles $\left(\mathrm{Ag}_{2} \mathrm{~S}\right.$ NPs) suspensions in milli-Q water were obtained from Applied Nanoparticles (Barcelona, Spain) with a mass concentration of $4.7 \mathrm{~g} / \mathrm{L}$. Three types of 50 $\mathrm{nm}$ silver nanoparticles with different surface modifications were purchased from Nanocomposix Inc. (San Diego, CA, USA); negatively charged lipoic acid BioPure (LA) AgNPs $(\mathrm{pH}=6.1)$ suspended in milli-Q water, negatively charged citrate BioPure (Cit) AgNPs ( $\mathrm{pH}=$ 7.4) suspended in $2 \mathrm{mM}$ citrate buffer, and positively charged branched polyethylenimine (BPEI) BioPure AgNPs $(\mathrm{pH}=7.0)$ suspended in milli-Q water. The silver mass concentration in the stock suspensions of the three AgNPs was $1 \mathrm{~g} / \mathrm{L}$. All AgNPs suspensions were stored at $4{ }^{\circ} \mathrm{C}$ in the dark. Silver nitrate $\left(\mathrm{AgNO}_{3}\right)$ (Sigma Aldrich; St. Louis, MO, USA) was used as a control (source of $\mathrm{Ag}^{+}$) in all experiments. Dilutions of the AgNPs or $\mathrm{AgNO}_{3}$ were freshly prepared for every exposure experiment in complete cell culture media (depending on the cell line used in the experiment). 5-Fluorouracil (5-FU) was purchased from Sigma-Aldrich.

\section{Physicochemical characterization of nanoparticles}

Hydrodynamic diameters of the AgNPs were determined using dynamic light scattering (DLS). Measurements were performed on samples containing $10 \mathrm{mg} / \mathrm{L}$ AgNPs suspended in nano-pure water using an ALV dynamic light scattering setup (ALV-Laser Vertriebsgesellschaft; Germany), consisting of a Thorn RFIB263KF photomultiplier detector, an ALV-SP/86 goniometer, an ALV 50/ $100 / 200 / 400 / 600 \mu \mathrm{m}$ pinhole detection system, an ALV7002 external correlator, and a Cobolt Samba-300 DPSS laser. The measurements were performed immediately after preparation at room temperature. For each condition, samples were analyzed in triplicate; each measurement consisted of 10 technical replicatemeasurements of $30 \mathrm{~s}$ each, at an angle of $90^{\circ}$. The results are expressed as the average hydrodynamic diameter $(\mathrm{nm}) \pm$ standard deviation (SD) that was calculated using AfterALV software (AfterALV 1.0d, Dullware; USA).

The total silver content of the AgNPs suspensions and $\mathrm{AgNO}_{3}$ solution was analyzed using a NexION 350D inductively coupled plasma mass spectrometer (ICP-MS) (PerkinElmer, Waltham, MA, USA). Before analysis, samples were digested using an aqua-regia $(1,3,70 \%$
$\mathrm{HNO}_{3}: 37 \% \mathrm{HCl}$ ) acid digestion for $30 \mathrm{~min}$ at $60^{\circ} \mathrm{C}$ and diluted with nano-pure water. Silver was measured using the selected element-monitoring mode with $\mathrm{m} / \mathrm{z}$ values of 107 and 109. A calibration curve of an ionic Ag standard $\left(\mathrm{NIST}-\mathrm{AgNO}_{3}\right.$ ) (Merck; Darmstadt, Germany) ranging from 0.1 to $50 \mu \mathrm{g} / \mathrm{L}$ was included. Rhodium (Merck) was used as an internal standard. The limit of detection (LODconc) and limit of quantification $\left(\mathrm{LOQ}_{\mathrm{conc}}\right)$ were estimated to be 2 and $6 \mathrm{ng} / \mathrm{L}$, respectively. The cell culture media (vehicle controls) did not contain detectable levels of Ag. All samples were analyzed in triplicate.

The particle sizes, size distributions, particle mass- and number-based concentrations of the AgNPs in the AgNPs suspensions and $\mathrm{AgNO}_{3}$ solution were quantified using single particle (sp) ICP-MS. The method for the spICPMS measurements was described previously [59] . Briefly, the sample flow rate to the nebulizer was determined before the start of each series of measurements. The dwell time was set at 3 milliseconds and the total acquisition time was set at $60 \mathrm{~s}$. A diluted suspension of $60 \mathrm{~nm}$ gold $(\mathrm{Au}) \mathrm{NPs}$ (Nanocomposix) with a mass concentration of $50 \mathrm{ng} / \mathrm{L}$ was used before each analysis to verify the performance of the ICP-MS and to determine the transport efficiency. A calibration curve of ionic silver (NIST$\mathrm{AgNO}_{3}$ ) with a concentration range of $0.1-20 \mu \mathrm{g} / \mathrm{L}$ was used for particle mass and size determination. The time scan data of the spICP-MS measurements were exported as .csv files, and the particle size, size distribution, and mass- and number-based concentrations were calculated from the spICP-MS data, using a dedicated spreadsheet. Details about the spreadsheet have been described previously [59]. The $\mathrm{LOD}_{\text {conc }}$ and $\mathrm{LOQ}_{\text {conc }}$ were estimated to be 20 and $67 \mathrm{ng} / \mathrm{L}$, respectively. The NP size was calculated based on the particle mass, assuming spherical particles. The size detection limit $\left(\mathrm{LOD}_{\text {size }}\right)$ was $20 \mathrm{~nm}$ and accordingly silver particles with sizes below this limit were included in the ionic silver fraction.

\section{Cell culture}

ES-D3 adherent mouse embryonic multipotent stem cells (mESCs; ATCC; Wesel, Germany) were used at passage numbers between 4 and 12. The cells were cultured and maintained in $25 \mathrm{~cm}^{2}$ cell culture flasks (Corning; Oneonta, NY, USA) coated with $0.1 \%$ gelatin at $37^{\circ} \mathrm{C}$ in a humidified $5 \% \mathrm{CO}_{2}$ atmosphere in complete cell culture medium $\left(\mathrm{DMEM}^{+}\right) . \mathrm{DMEM}^{+}$was prepared by supplementing HyClone AdvanceSTEM Low Osmo Dulbecco's modified Eagle's medium (DMEM) culture medium (GE Healthcare Life Sciences; USA) with 20\% (v/v) heat inactivated Fetal Bovine Serum (FBS) (ATCC; Manassas, VA, USA), 1\% (v/v) Penicillin-StreptomycinGlutamine 10,000 units penicillin, $10 \mathrm{mg}$ streptomycin/ $\mathrm{mL}$, and $29.2 \mathrm{mg} / \mathrm{mL}$ L-glutamine (Gibco, Life Technologies; Paisley, UK). The cells were sub-cultured every 2- 
3 days using non-enzymatic cell dissociation solution (Sigma Aldrich) to detach the cells. The cells were maintained in an undifferentiated state by adding mouse leukemia inhibitory factor (mLIF; Sigma-Aldrich).

The adherent placental choriocarcinoma clone b30 (BeWo b30) was kindly provided by the Institute of Public Health of the Faculty of Health Sciences (University of Copenhagen, Denmark) with permission from Dr. Alan Schwartz (Washington University, St. Louis, MO) and confirmed to be mycoplasma free. The cells were used at passage numbers between 14 and 22 . The cells were cultured and maintained in $75 \mathrm{~cm}^{2}$ cell culture flasks (Corning) at $37^{\circ} \mathrm{C}$ in a humidified $5 \% \mathrm{CO}_{2}$ atmosphere in complete cell culture medium $\left(\mathrm{DMEM}^{+}\right)$. The $\mathrm{DMEM}^{+}$was prepared by supplementing DMEM culture medium-GlutaMAX supplement-pyruvate (Gibco, Life Technologies) with $10 \%(\mathrm{v} / \mathrm{v})$ heat inactivated FBS (Gibco, Life Technologies), 1\% (v/v) PenicillinStreptomycin 10,000 units penicillin, and $10 \mathrm{mg}$ streptomycin/mL (Gibco, Life Technologies). The cells were sub-cultured every 3-4 days using trypsin-EDTA (Sigma Aldrich) to detach the cells.

\section{Cell viability}

Cytotoxic effects of the AgNPs and $\mathrm{AgNO}_{3}$ were evaluated using the ATPlite luminescence assay system (PerkinElmer; Waltham MA, USA). In 96-well black flat bottom plates (Greiner bio-one; Frickenhausen Germany) each well was seeded with $100 \mu \mathrm{L}$ of $1 \times 10^{5}$ cells $/ \mathrm{mL}$ BeWo b30 cell suspension in $\mathrm{DMEM}^{+}$. Plates were incubated at $37^{\circ} \mathrm{C}$ and $5 \% \mathrm{CO}_{2}$ for $24 \mathrm{~h}$. The attached cells were then washed with $100 \mu \mathrm{L} /$ well pre-warmed HBSS buffer w/o phenol red and exposed to $100 \mu \mathrm{L} /$ well of freshly prepared dilutions $(0.1-100 \mathrm{mg} / \mathrm{L})$ of $\mathrm{AgNPs}$ or $\mathrm{AgNO}_{3}$. After $24 \mathrm{~h}$ exposure, the exposure medium was aspirated and $50 \mu \mathrm{L} /$ well of mammalian cell lysis solution were added and the plates were shaken $(700 \mathrm{rpm})$ for $5 \mathrm{~min}$ at room temperature in an orbital shaker (Heidolph-Trimax 1000; Schwabach, Germany). Next, $50 \mu \mathrm{L} /$ well of substrate solution were added and the plates were shaken $(700 \mathrm{rpm})$ for $5 \mathrm{~min}$ at room temperature and then incubated for $10 \mathrm{~min}$ in the dark at room temperature. The luminescence was then measured using a plate reader (BioTek Synergy ${ }^{\text {mix }}$ HT Multi-Mode Microplate reader; Winooski VT, USA). The cell viability was expressed as percentage of the control. $\mathrm{DMEM}^{+}$was used as a negative control and Triton-X100 (0.25\%) (Sigma-Aldrich) was used as a positive control.

BeWo b30 placental cell layer barrier integrity assessment BeWo b30 cells were grown at a density of $1 \times 10^{4}$ cells/ $\mathrm{cm}^{2}$ on the upper side of transwell polycarbonate inserts ( $3 \mu \mathrm{m}$ pore size, $1.12 \mathrm{~cm}^{2}$ surface area) (Corning) for 6 days (based on [16]. The integrity of the cell layer was assessed before exposure by measuring the transepithelial electrical resistance (TEER) using a Millicell ERS-2 Epithelial Volt- Ohm Meter (Millipore; Darmstadt, Germany). On day 6 post-seeding, only inserts with TEER values between 80 and $100 \Omega . \mathrm{cm}^{2}$ were used for further experiments. The TEER was also measured after exposure to confirm the barrier integrity and comparability of the TEER values before and after exposure.

Additionally, the cell layer integrity was evaluated before exposure to AgNPs suspensions and $\mathrm{AgNO}_{3}$ solution by measuring the transport efficacy of three different markers namely; lucifer yellow (LY) (Sigma-Aldrich) and low $(4 \mathrm{kDa})$ and high $(10 \mathrm{kDa})$ molecular weight fluorescein isothiocyanate dextrans (FITC-D) (Sigma-Aldrich). To the apical compartment, $500 \mu \mathrm{L} / \mathrm{in}$ sert of $1 \mathrm{mg} / \mathrm{mL}$ of each of the integrity markers in $\mathrm{DMEM}^{+}$were added separately. After $1 \mathrm{~h}$ incubation at $37^{\circ} \mathrm{C}$, the basolateral medium was collected, and the transport of the markers was determined by measuring the fluorescence at $485 / 530 \mathrm{~nm}$ using a fluorescence plate reader (BioTek Synergy ${ }^{\mathrm{Tm}}$ HT Multi-Mode Microplate reader) and expressed as a percentage of the exposure concentration.

\section{BeWo b30 cellular uptake/association and transport of AgNPs and $\mathrm{AgNO}_{3}$}

Six-day old BeWo b30 cell layer were exposed apically to $500 \mu \mathrm{L} /$ insert of $1 \mathrm{mg} / \mathrm{L}$ of the AgNPs suspensions or the $\mathrm{AgNO}_{3}$ solution for $4,6,18$, and $24 \mathrm{~h}$ at $37^{\circ} \mathrm{C}$ and $5 \% \mathrm{CO}_{2}$. Then, the media from the apical and basolateral compartments were collected. The cells were collected by trypsinzation $(500 \mu \mathrm{L})$ and sonication $(40 \mathrm{kHz}$ for $15-20 \mathrm{~min}$ ) to form cell lysate. The total silver content in all samples (apical, basolateral and cell lysate) was analyzed using ICP-MS. The particle size, size distribution, and mass- and number-based concentration in in all samples (apical, basolateral and cell lysate) after $24 \mathrm{~h}$ exposure using spICP-MS. The total Ag mass balance in the placental transport model upon exposure to $\mathrm{AgNPs}$ and $\mathrm{AgNO}_{3}$ was $>90 \%$.

\section{In vitro developmental toxicity assessment of AgNPs and $\mathrm{AgNO}_{3}$}

For the assessment of cell viability of mESCs used in the EST, the potential cytotoxicity of AgNPs and $\mathrm{AgNO}_{3}$ was evaluated after 24 and $120 \mathrm{~h}$ exposure, reflecting the shortest and longest exposure time during the EST. Each well was seeded with $100 \mu \mathrm{L}$ of a $2 \times 10^{4}$ (for the $24 \mathrm{~h}$ exposure) or $1 \times 10^{3}$ cells $/ \mathrm{mL}$ (for the $120 \mathrm{~h}$ exposure) cell suspension in $\mathrm{DMEM}^{+}$without mLIF in 96-well black flat bottom plates (Greiner bio-one). The viability was assessed as mentioned above.

The potential of the AgNPs and $\mathrm{AgNO}_{3}$ to inhibit mESCs differentiation into beating cardiomyocytes was evaluated using the EST. The cells were exposed from day 3 to 10 of the 10-day mESCs differentiation. The 
wells of the 96-well plate (Corning) were filled with $200 \mu \mathrm{L} /$ well PBS. To start the assay hanging droplets $(20 \mu \mathrm{L})$ of a $3.75 \times 10^{4}$ cells $/ \mathrm{mL}$ mESCs suspension were placed on the inner side of a lid of a 96-well plate. Sterile lids of Eppendorf tubes were placed on each corner of the 96-well plate lid to avoid contact of the droplets with the plate. Then the plate was sealed with Micropore tape ( $3 \mathrm{M}$; Germany) to prevent evaporation of the hanging drops. The plates were incubated for three days at $37^{\circ} \mathrm{C}$ and $5 \% \mathrm{CO}_{2}$ in a humidified atmosphere to allow the formation of embryoid bodies (EBs). On day 3, the formed EBs were transferred to $6 \mathrm{~cm}$ non-treated tissue culture petri dishes (Greiner bio-one) with $5 \mathrm{~mL}$ of $\mathrm{DMEM}^{+}$containing AgNPs or $\mathrm{AgNO}_{3}$ and incubated at $37^{\circ} \mathrm{C}$ and $5 \% \mathrm{CO}_{2}$ in a humidified atmosphere for 2 days to allow growth of the EBs. A concentration range between $0.1-25 \mathrm{mg} / \mathrm{L}$ was used for each type of AgNPs, while for $\mathrm{AgNO}_{3}$ a concentration range between 0.05-5 $\mathrm{mg} / \mathrm{L}$ was used. $\mathrm{DMEM}^{+}$was used as a negative control and $1 \mu \mathrm{M} 5$-FU was used as a positive control. On day 5 , the EBs were transferred to a 24-well plate (Corning) where each well contained one $\mathrm{EB}$ in $1 \mathrm{~mL}$ of the same concentration of AgNPs or $\mathrm{AgNO}_{3}$. On day 10, using a light microscope, the wells were visually inspected for contracting cardiomyocytes. The number of wells/plate containing contracting cardiomyocytes were recorded where the experiment was considered valid if at least 21 of the 24 wells of the negative control sample contained contracting cardiomyocytes. For each concentration of each treatment, the fraction of successfully differentiated EBs into contracting cardiomyocytes was calculated and expressed as percentages of the number of wells with beating cardiomyocytes from the number of wells initially seeded with EBs for each concentration.

\section{Characterization of AgNPs dissolution in $\mathrm{DMEM}^{+}$}

The stability and dissolution properties of the four AgNPs were evaluated in $1 \mathrm{mg} / \mathrm{L}$ AgNPs suspensions in $\mathrm{DMEM}^{+}$ upon incubation in the dark at $37^{\circ} \mathrm{C}$. At 0 and $120 \mathrm{~h}$, aliquots from each AgNPs suspension were extracted for analysis. spICP-MS was used to quantify the total $\mathrm{Ag}$ content, particle size, size distribution, and mass- and number-based concentration in all samples as described earlier.

\section{Confocal microscopy of differentiated cardiomyocytes}

For confocal imaging, the EBs formed in the EST were transferred into 8 - well $\mu$-Slides (Ibidi; Gräfelfing, Germany) for exposure and differentiation into cardiomyocytes. The EBs were exposed to the AgNPs suspensions or $\mathrm{AgNO}_{3}$ solution using similar conditions as used in the EST. After 5 days exposure, the exposure medium was discarded, and the cells were fixed with $4 \%$ paraformaldehyde (Sigma-Aldrich) for $15 \mathrm{~min}$ at room temperature. The cells were washed 3 times with PBS for $5 \mathrm{~min}$ after discarding the fixation solution. The cells were permeabilized with $0.25 \%$ Triton X-100/PBS for $15 \mathrm{~min}$ at room temperature. The cells were then washed again 3 times with PBS for $5 \mathrm{~min}$ before incubating them with the blocking buffer (1\%BSA in PBS) for $30 \mathrm{~min}$ at room temperature. After discarding the blocking buffer, Phalloidin - Alexa 488 (6 units) (Dyomics; Jena, Germany) was added to stain cellular actin and the cells were incubated for $30 \mathrm{~min}$ at room temperature. Cells were washed three times with PBS before incubating the cells for $10 \mathrm{~min}$ at room temperature with RedDot-2 (1: 200) (Biotium; Fremont, CA, USA) to stain the nuclei. Finally, the cells were washed with PBS and stored in the dark until analysis. The cells were analyzed using a confocal laser scanning microscope (SP5X-SMD; Leica Microsystems, Wetzlar, Germany). Samples were excited with 665 and $495 \mathrm{~nm}$ lasers and backscattered light was used to detect AgNPs using a $543 \mathrm{~nm}$ laser.

\section{Statistical analysis}

Each data point represents the average of three replicates $(n=3)$ and the results are shown as mean \pm standard deviation. Prism (v.8.0.1; GraphPad, USA) software was used for statistical analysis using a one-way analysis of variance (ANOVA) with a Bonferroni's post-test. A $p$ value $<0.05$ was considered significant.

\section{Supplementary information}

Supplementary information accompanies this paper at https://doi.org/10. 1186/s12989-020-00342-6.

Additional file 1. Supplementary information accompanies this paper

\section{Acknowledgements}

We thank Prof.Dr.ir. Ivonne M.C.M. Rietjens (Wageningen University, the Netherlands) for critically reviewing the manuscript.

\section{Authors' contributions}

$\mathrm{AA}, \mathrm{MZ}$ and $\mathrm{HB}$ conceived the experiments, AA performed all experiments and wrote manuscript with $M Z$ and $H B, R P$ critically discussed the NP detection and characterization experiments and results. The authors read and approved the final manuscript.

\section{Funding}

This work was supported by the NFP grant to AA and the EU H2O2O project NanoFASE (grant no. 646002) to MZ, and RP.

Availability of data and materials

The datasets used and/or analyzed during the current study are available from the corresponding author on reasonable request.

Ethics approval and consent to participate Not applicable.

Consent for publication

Not applicable.

Competing interests

The authors declare that they have no competing interests. 


\section{Author details}

'Division of Toxicology, Wageningen University, P.O. box 8000, 6700, EA, Wageningen, the Netherlands. ${ }^{2}$ Wageningen Food Safety Research (WFSR), P.O. Box 230, 6700, AE, Wageningen, the Netherlands. ${ }^{3}$ Food Science and Technology Department, Faculty of Agriculture - Alexandria University, Alexandria, Egypt.

Received: 5 December 2019 Accepted: 28 February 2020

Published online: 10 March 2020

\section{References}

1. Missaoui WN, Arnold RD, Cummings BS. Toxicological status of nanoparticles: what we know and what we don't know. Chem Biol Interact. 2018;295:1-12. https://doi.org/10.1016/j.cbi.2018.07.015 https://www.ncbi. nlm.nih.gov/pubmed/30048623.

2. Prajitha N, Athira SS, Mohanan PV. Bio-interactions and risks of engineered nanoparticles. Environ Res. 2019;172:98-108. https://doi.org/10.1016/j.envres. 2019.02.003 https://www.ncbi.nlm.nih.gov/pubmed/30782540.

3. Nam NH, Luong NH. Nanoparticles: synthesis and applications. In: Grumezescu V, Grumezescu AM, editors. Materials for biomedical engineerin. Amsterdam: Elsevier; 2019. p. 211-40. ISBN: 9780081028155.

4. Thomas TA. Nanotechnology in consumer products : addressing potential health and safety implications for consumers. In: Monteiro-Riviere NA, Tran $\mathrm{CL}$, editors. Nanotoxicology : Progress toward nanomedicine. 2nd ed. Boca Raton: CRC Press; 2014. p. 97-112.

5. Samberg ME, Loboa EG, Oldenburg SJ, Monteiro-Riviere NA. Silver nanoparticles do not influence stem cell differentiation but cause minimal toxicity. Nanomedicine (Lond). 2012;7(8):1197-209. https://doi.org/10.2217/ nnm.12.18 https://www.ncbi.nlm.nih.gov/pubmed/22583572.

6. Samberg ME, Monteiro-Riviere NA. Silver nanoparticles in biomedical applications. In: Monteiro-Riviere NA, Tran CL, editors. Nanotoxicology : Progress toward nanomedicine. 2nd ed. Boca Raton: CRC Press; 2014. p. 405-21.

7. Dekkers S, Oomen AG, Bleeker EA, Vandebriel RJ, Micheletti C, Cabellos J, et al. Towards a nanospecific approach for risk assessment. Regul Toxicol Pharmacol. 2016;80:46-59. https://doi.org/10.1016/j.yrtph.2016.05.037 https:// www.ncbi.nlm.nih.gov/pubmed/27255696.

8. Lynch I, Weiss C, Valsami-Jones E. A strategy for grouping of nanomaterials based on key physico-chemical descriptors as a basis for safer-by-design NMs. Nano Today. 2014;9(3):266-70. https://doi.org/10.1016/j.nantod.2014. $05.001<$ Go to $|S|>: / /$ WOS:000341481000005.

9. Arts JH, Hadi M, Irfan MA, Keene AM, Kreiling R, Lyon D, et al. A decisionmaking framework for the grouping and testing of nanomaterials (DF4nanoGrouping). Regul Toxicol Pharmacol. 2015;71(2 Suppl):S1-27. https://doi.org/10.1016/j.yrtph.2015.03.007 https://www.ncbi.nlm.nih.gov/ pubmed/25818068.

10. Liu SQ, Wang C, Hou J, Wang PF, Miao LZ, Li TF. Effects of silver sulfide nanoparticles on the microbial community structure and biological activity of freshwater biofilms. Environmen Sci-Nano. 2018;5(12):2899-908. https:// doi.org/10.1039/c8en00480c <Go to ISI >://WOS:000452777300010.

11. Loeschner K, Hadrup N, Qvortrup K, Larsen A, Gao X, Vogel U, et al. Distribution of silver in rats following 28 days of repeated oral exposure to silver nanoparticles or silver acetate. Part Fibre Toxicol. 2011;8(1):18. https:// doi.org/10.1186/1743-8977-8-18 https://www.ncbi.nlm.nih.gov/ pubmed/21631937.

12. Li L, Xu Z, Wimmer A, Tian Q, Wang X. New insights into the stability of silver sulfide nanoparticles in surface water: dissolution through hypochlorite oxidation. Environ Sci Technol. 2017;51(14):7920-7. https://doi.org/10.1021/acs. est.7b01738 https://www.ncbi.nlm.nih.gov/pubmed/28608678.

13. Wang P, Lombi E, Sun SK, Scheckel KG, Malysheva A, McKenna BA, et al. Characterizing the uptake, accumulation and toxicity of silver sulfide nanoparticles in plants. Environmen Sci-Nano. 2017;4(2):448-60. https://doi. org/10.1039/c6en00489j <Go to ISI>://WOS:000395876000018.

14. Abdelkhaliq A, van der Zande M, Undas AK, Peters RJB, Bouwmeester H. Impact of in vitro digestion on gastrointestinal fate and uptake of silver nanoparticles with different surface modifications. Nanotoxicology. 2019:116. https://doi.org/10.1080/17435390.2019.1675794 https://www.ncbi.nlm. nih.gov/pubmed/31648587.

15. van der Zande M, Vandebriel RJ, Van Doren E, Kramer E, Herrera Rivera Z, Serrano-Rojero CS, et al. Distribution, elimination, and toxicity of silver nanoparticles and silver ions in rats after 28-day oral exposure. ACS Nano.
2012;6(8):7427-42. https://doi.org/10.1021/nn302649p https://www.ncbi.nlm. nih.gov/pubmed/22857815.

16. Cartwright L, Poulsen MS, Nielsen HM, Pojana G, Knudsen LE, Saunders M, et al. In vitro placental model optimization for nanoparticle transport studies. Int J Nanomedicine. 2012;7:497-510. https://doi.org/10.2147/IJN. S26601 https://www.ncbi.nlm.nih.gov/pubmed/22334780.

17. Saunders M. Transplacental transport of nanomaterials. Wiley Interdiscip Rev Nanomed Nanobiotechnol. 2009;1(6):671-84. https://doi.org/10.1002/wnan. 53 https://www.ncbi.n/m.nih.gov/pubmed/20049824.

18. Aengenheister $L$, Keevend $K$, Muoth $C$, Schonenberger R, Diener L, Wick P, et al. An advanced human in vitro co-culture model for translocation studies across the placental barrier. Sci Rep. 2018;8(1):5388. https://doi.org/10.1038/ s41598-018-23410-6 https:/www.ncbi.n/m.nih.gov/pubmed/29599470.

19. Tran DN, Ota LC, Jacobson JD, Patton WC, Chan PJ. Influence of nanoparticles on morphological differentiation of mouse embryonic stem cells. Fertil Steril. 2007;87(4):965-70. https://doi.org/10.1016/j.fertnstert.2006. 07.1520 https://www.ncbi.nlm.nih.gov/pubmed/17140568.

20. Muoth C, Aengenheister L, Kucki M, Wick P, Buerki-Thurnherr T. Nanoparticle transport across the placental barrier: pushing the field forward! Nanomedicine (Lond). 2016;11(8):941-57. https://doi.org/10.2217/nnm-20150012 https://www.ncbi.nlm.nih.gov/pubmed/26979802.

21. Aengenheister L, Dietrich D, Sadeghpour A, Manser P, Diener L, Wichser A, et al. Gold nanoparticle distribution in advanced in vitro and ex vivo human placental barrier models. J Nanobiotechnol. 2018;16(1):79. https://doi.org/10. 1186/s12951-018-0406-6 https://www.ncbi.nlm.nih.gov/pubmed/30309365.

22. Levkovitz R, Zaretsky U, Gordon Z, Jaffa AJ, Elad D. In vitro simulation of placental transport: part I. biological model of the placental barrier. Placenta. 2013;34(8):699-707. https://doi.org/10.1016/j.placenta.2013.03.014 https:// www.ncbi.nlm.nih.gov/pubmed/23764139.

23. Wick P, Malek A, Manser P, Meili D, Maeder-Althaus X, Diener L, et al. Barrier capacity of human placenta for nanosized materials. Environ Health Perspect. 2010;118(3):432-6. https://doi.org/10.1289/ehp.0901200 https:// www.ncbi.nlm.nih.gov/pubmed/20064770.

24. Poulsen MS, Mose T, Maroun LL, Mathiesen L, Knudsen LE, Rytting E. Kinetics of silica nanoparticles in the human placenta. Nanotoxicology. 2015; 9 Suppl 1(sup1):79-86. https://doi.org/10.3109/17435390.2013.812259 https://www.ncbi.nlm.nih.gov/pubmed/23742169.

25. Omata W, Ackerman WE, Vandre DD, Robinson JM. Trophoblast cell fusion and differentiation are mediated by both the protein kinase $C$ and a pathways. PLoS One. 2013;8(11):e81003. https://doi.org/10.1371/journal. pone.0081003 https://www.ncbi.nlm.nih.gov/pubmed/24236208.

26. Correia Carreira S, Walker L, Paul K, Saunders M. The toxicity, transport and uptake of nanoparticles in the in vitro BeWo b30 placental cell barrier model used within NanoTEST. Nanotoxicology. 2015;9 Suppl 1(sup1):66-78. https://doi.org/10.3109/17435390.2013.833317 https://www.ncbi.nlm.nih. gov/pubmed/23927440.

27. Bode CJ, Jin H, Rytting E, Silverstein PS, Young AM, Audus KL. In vitro models for studying trophoblast transcellular transport. Methods Mol Med. 2006;122:225-39. https://doi.org/10.1385/1-59259-989-3:225 https://www. ncbi.n/m.nih.gov/pubmed/16511984.

28. Rytting E. Exploring the interactions of nanoparticles with multiple models of the maternal--fetal interface. Nanotoxicology. 2015;9 Suppl 1(sup1):137-8. https://doi.org/10.3109/17435390.2013.877997 https://www.ncbi.nlm.nih. gov/pubmed/25923351.

29. Parry S, Zhang J. Multidrug resistance proteins affect drug transmission across the placenta. Am J Obstet Gynecol. 2007;196(5):476. https://doi.org/10.1016/j. ajog.2007.02.019 e1-6. https://www.ncbi.nlm.nih.gov/pubmed/17466710.

30. Vardhana PA, IIIsley NP. Transepithelial glucose transport and metabolism in BeWo choriocarcinoma cells. Placenta. 2002;23(8-9):653-60. https://doi.org/ 10.1053/plac.2002.0857 https://www.ncbi.nlm.nih.gov/pubmed/12361684.

31. Li H, van Ravenzwaay B, Rietjens IM, Louisse J. Assessment of an in vitro transport model using BeWo b30 cells to predict placental transfer of compounds. Arch Toxicol. 2013;87(9):1661-9. https://doi.org/10.1007/ s00204-013-1074-9 https://www.ncbi.nlm.nih.gov/pubmed/23689295.

32. Chaby G, Viseux V, Poulain JF, De Cagny B, Denoeux JP, Lok C. Topical silver sulfadiazine-induced acute renal failure. Ann Dermatol Venereol. 2005; 132(11 Pt 1):891-3. https://doi.org/10.1016/s0151-9638(05)79509-0 https:// www.ncbi.nlm.nih.gov/pubmed/16327720.

33. Bader KF. Organ deposition of silver following silver nitrate therapy of burns. Plast Reconstr Surg. 1966;37(6):550-1. https://doi.org/10.1097/00006534196606000-00012 https://www.ncbi.nlm.nih.gov/pubmed/5932415. 
34. Hadrup N, Sharma AK, Loeschner K. Toxicity of silver ions, metallic silver, and silver nanoparticle materials after in vivo dermal and mucosal surface exposure: a review. Regul Toxicol Pharmacol. 2018;98:257-67. https://doi.org/ 10.1016/j.yrtph.2018.08.007 https://www.ncbi.nlm.nih.gov/pubmed/30125612.

35. Dimopoulou M, Verhoef A, Gomes CA, van Dongen CW, Rietjens I, Piersma $\mathrm{AH}$, et al. A comparison of the embryonic stem cell test and whole embryo culture assay combined with the BeWo placental passage model for predicting the embryotoxicity of azoles. Toxicol Lett. 2018;286:10-21. https://doi.org/10.1016/j.toxlet.2018.01.009 https://www.ncbi.nlm.nih.gov/ pubmed/29337257.

36. Li H, Flick B, Rietjens IM, Louisse J, Schneider S, van Ravenzwaay B. Extended evaluation on the ES-D3 cell differentiation assay combined with the BeWo transport model, to predict relative developmental toxicity of triazole compounds. Arch Toxicol. 2016;90(5):1225-37. https://doi.org/10.1007/ s00204-015-1541-6 https://www.ncbi.nlm.nih.gov/pubmed/26047666.

37. Li H, Rietjens IM, Louisse J, Blok M, Wang X, Snijders L, et al. Use of the ESD3 cell differentiation assay, combined with the BeWo transport model, to predict relative in vivo developmental toxicity of antifungal compounds. Toxicol in Vitro. 2015;29(2):320-8. https://doi.org/10.1016/j.tiv.2014.11.012 https://www.ncbi.nlm.nih.gov/pubmed/25489799.

38. Lee HY, Inselman AL, Kanungo J, Hansen DK. Alternative models in developmental toxicology. Syst Biol Reprod Med. 2012;58(1):10-22. https:// doi.org/10.3109/19396368.2011.648302 https://www.ncbi.nlm.nih.gov/ pubmed/22239077.

39. Seiler AE, Spielmann $H$. The validated embryonic stem cell test to predict embryotoxicity in vitro. Nat Protoc. 2011;6(7):961-78. https://doi.org/10. 1038/nprot.2011.348 https://www.ncbi.nlm.nih.gov/pubmed/21720311.

40. Tandon S, Jyoti S. Embryonic stem cells: an alternative approach to developmental toxicity testing. J Pharm Bioallied Sci. 2012;4(2):96-100. https://doi.org/10.4103/0975-7406.94808 https://www.ncbi.nlm.nih.gov/ pubmed/22557918.

41. Gao X, Topping VD, Keltner Z, Sprando RL, Yourick JJ. Toxicity of nano- and ionic silver to embryonic stem cells: a comparative toxicogenomic study. J Nanobiotechnol. 2017;15(1):31. https://doi.org/10.1186/s12951-017-0265-6 https://www.ncbi.nlm.nih.gov/pubmed/28399865.

42. Kloet SK, Walczak AP, Louisse J, van den Berg HH, Bouwmeester H, Tromp P, et al. Translocation of positively and negatively charged polystyrene nanoparticles in an in vitro placental model. Toxicol in Vitro. 2015;29(7): 1701-10. https://doi.org/10.1016/j.tiv.2015.07.003 https://www.ncbi.nlm.nih. gov/pubmed/26145586.

43. Vidmar J, Loeschner $K$, Correia M, Larsen EH, Manser P, Wichser A, et al. Translocation of silver nanoparticles in the ex vivo human placenta perfusion model characterized by single particle ICP-MS. Nanoscale. 2018; 10(25):11980-91. https://doi.org/10.1039/c8nr02096e https://www.ncbi.nlm. nih.gov/pubmed/29904776.

44. Behra R, Sigg L, Clift MJ, Herzog F, Minghetti M, Johnston B, et al. Bioavailability of silver nanoparticles and ions: from a chemical and biochemical perspective. J R Soc Interface. 2013;10(87):20130396. https://doi. org/10.1098/rsif.2013.0396 https://www.ncbi.nlm.nih.gov/pubmed/23883950.

45. van der Zande M, Undas AK, Kramer E, Monopoli MP, Peters RJ, Garry D, et al. Different responses of Caco-2 and MCF-7 cells to silver nanoparticles are based on highly similar mechanisms of action. Nanotoxicology. 2016; 10(10):1431-41. https://doi.org/10.1080/17435390.2016.1225132 https:// www.ncbi.nlm.nih.gov/pubmed/27597447.

46. Graf C, Nordmeyer D, Sengstock C, Ahlberg S, Diendorf J, Raabe J, et al. Shape-dependent dissolution and cellular uptake of silver nanoparticles. Langmuir. 2018;34(4):1506-19. https://doi.org/10.1021/acs.langmuir.7b03126 https://www.ncbi.nlm.nih.gov/pubmed/29272915.

47. Myllynen PK, Loughran MJ, Howard CV, Sormunen R, Walsh AA, Vahakangas $\mathrm{KH}$. Kinetics of gold nanoparticles in the human placenta. Reprod Toxicol. 2008;26(2):130-7. https://doi.org/10.1016/j.reprotox.2008.06.008 https://www. ncbi.nlm.nih.gov/pubmed/18638543.

48. Fennell TR, Mortensen NP, Black SR, Snyder RW, Levine KE, Poitras E, et al. Disposition of intravenously or orally administered silver nanoparticles in pregnant rats and the effect on the biochemical profile in urine. J Appl Toxicol. 2017;37(5):530-44. https://doi.org/10.1002/jat.3387 https://www.ncbi. nlm.nih.gov/pubmed/27696470.

49. Wu J, Yu C, Tan Y, Hou Z, Li M, Shao F, et al. Effects of prenatal exposure to silver nanoparticles on spatial cognition and hippocampal neurodevelopment in rats. Environ Res. 2015;138:67-73. https://doi.org/10. 1016/j.envres.2015.01.022 https://www.ncbi.nlm.nih.gov/pubmed/25701810.
50. Lee Y, Choi J, Kim P, Choi K, Kim S, Shon W, et al. A transfer of silver nanoparticles from pregnant rat to offspring. Toxicol Res. 2012;28(3):139-41. https://doi.org/10.5487/TR.2012.28.3.139 https://www.ncbi.nlm.nih.gov/ pubmed/24278602

51. Lyon TD, Patriarca M, Howatson G, Fleming PJ, Blair PS, Fell GS. Age dependence of potentially toxic elements ( $\mathrm{Sb}, \mathrm{cd}, \mathrm{Pb}, \mathrm{ag}$ ) in human liver tissue from paediatric subjects. J Environ Monit. 2002;4(6):1034-9. https:// doi.org/10.1039/b205972j https://www.ncbi.nlm.nih.gov/pubmed/12509062.

52. Menezes $V$, Malek A, Keelan JA. Nanoparticulate drug delivery in pregnancy: placental passage and fetal exposure. Curr Pharm Biotechnol. 2011;12(5): 731-42. https://doi.org/10.2174/138920111795471010 https://www.ncbi.nlm. nih.gov/pubmed/21342124.

53. Corradi S, Dakou E, Yadav A, Thomassen LC, Kirsch-Volders M, Leyns L. Morphological observation of embryoid bodies completes the in vitro evaluation of nanomaterial embryotoxicity in the embryonic stem cell test (EST). Toxicol in Vitro. 2015;29(7):1587-96. https://doi.org/10.1016/j.tiv.2015. 06.015 https://www.ncbi.nlm.nih.gov/pubmed/26093180.

54. Vecchione L, Massimiani M, Camaioni A, Sifrani L, Magrini A, Pietroiusti A, et al. A comparative study of metal oxide nanoparticles embryotoxicity using the embryonic stem cell test. In: BioNanoMaterials, vol. 14; 2013. p. 61.

55. Park MV, Neigh AM, Vermeulen JP, de la Fonteyne $L$, Verharen HW, Briede $J$ J, et al. The effect of particle size on the cytotoxicity, inflammation, developmental toxicity and genotoxicity of silver nanoparticles. Biomaterials. 2011;32(36):9810-7. https://doi.org/10.1016/j.biomaterials.2011.08.085 https:// www.ncbi.nlm.nih.gov/pubmed/21944826.

56. Bouwmeester H, Poortman J, Peters RJ, Wijma E, Kramer E, Makama S, et al. Characterization of translocation of silver nanoparticles and effects on whole-genome gene expression using an in vitro intestinal epithelium coculture model. ACS Nano. 2011;5(5):4091-103. https://doi.org/10.1021/ nn2007145 https://www.ncbi.nlm.nih.gov/pubmed/21480625.

57. Reinsch BC, Levard C, Li Z, Ma R, Wise A, Gregory KB, et al. Sulfidation of silver nanoparticles decreases Escherichia coli growth inhibition. Environ Sci Technol. 2012;46(13):6992-7000. https://doi.org/10.1021/es203732x https:// www.ncbi.nlm.nih.gov/pubmed/22296331.

58. Yin Y, Yu S, Shen M, Liu J, Jiang G. Fate and transport of silver nanoparticles in the environment. In: Liu J, Jiang G, editors. Silver nanoparticles in the environment. Berlin, Heidelberg: Springer Berlin Heidelberg; 2015. p. 73-108.

59. Peters R, Herrera-Rivera Z, Undas A, van der Lee M, Marvin H, Bouwmeester $\mathrm{H}$, et al. Single particle ICP-MS combined with a data evaluation tool as a routine technique for the analysis of nanoparticles in complex matrices. J Anal Atom Spectrom. 2015;30(6):1274-85. https://doi.org/10.1039/ c4ja00357h < Go to ISI >:/MOS:000355559500007.

\section{Publisher's Note}

Springer Nature remains neutral with regard to jurisdictional claims in published maps and institutional affiliations.

Ready to submit your research? Choose BMC and benefit from:

- fast, convenient online submission

- thorough peer review by experienced researchers in your field

- rapid publication on acceptance

- support for research data, including large and complex data types

- gold Open Access which fosters wider collaboration and increased citations

- maximum visibility for your research: over $100 \mathrm{M}$ website views per year

At BMC, research is always in progress.

Learn more biomedcentral.com/submissions 